\title{
Geoelectric Evaluation of Groundwater Potential and Vulnerability of Overburden Aquifers at Onibu-Eja Active Open Dumpsite, Osogbo, Southwestern Nigeria
}

\author{
Nicholas U. Ugwu ${ }^{1,2 *}$, Rubeni T. Ranganai' ${ }^{1}$, Rapelang E. Simon ${ }^{1}$, Ghebrebrhan Ogubazghi ${ }^{3}$ \\ ${ }^{1}$ Department of Physics, University of Botswana, Gaborone, Botswana \\ ${ }^{2}$ The Federal Polytechnic Ede, Ede, Nigeria \\ ${ }^{3}$ Eritrea Institute of Technology, Mai Nefhi, Asmara, Eritrea \\ Email: "nuumay665@gmail.com
}

Received 8 February 2016; accepted 20 March 2016; published 23 March 2016

Copyright (C) 2016 by authors and Scientific Research Publishing Inc.

This work is licensed under the Creative Commons Attribution International License (CC BY). http://creativecommons.org/licenses/by/4.0/

(c) (i) Open Access

\begin{abstract}
Electrical resistivity method was used to assess groundwater potential and vulnerability of overburden aquifers at Onibu-Eja active open dumpsite, Osogbo, Southwestern Nigeria. Eighteen Vertical Electrical Sounding (VES) points and five 2-D imaging profiles established in five traverses at the periphery of the dumpsite were surveyed and analysed. The subsurface comprised of thin topsoil (resistivity 65 - $998 \Omega \mathrm{m}$ ); heterogeneous weathered layer with resistivity $63-333 \Omega \mathrm{m}$ and thickness 0.7 - $8.5 \mathrm{~m}$; weathered basement (resistivity $31-1253 \Omega \mathrm{m}$ and thickness 0.7 - $27.0 \mathrm{~m}$ ) and fractured/fresh basement (resistivity $36-6213 \Omega \mathrm{m}$ ). The 2-D inverse model of the profiles delineated low resistivity values ranging from 5 to $100 \Omega \mathrm{m}$ at a depth range of $10-20 \mathrm{~m}$ along traverses TR1-TR3 which is attributed to leachate percolation close to the dumpsite. The weathered basement was inclined relative to the dumpsite. The total overburden thickness varies from 6.9 to $33.7 \mathrm{~m}$, with 20 and $40 \mathrm{~m}$ generally recommended as productive for groundwater abstraction in Southwestern Nigeria occurring in $61 \%$ of the area. Further, about $85 \%$ of the weathered layer resistivity values fall within medium groundwater potential $(100-250 \Omega \mathrm{m})$ and high groundwater potential $(>\mathbf{2 5 0} \Omega \mathrm{m})$. The ranking of groundwater potential as a function of saprolite (weathered basement) resistivity showed that $72 \%$ of the study area is characterized by optimum weathering (20 - $100 \Omega \mathrm{m})$ and is classified as good groundwater potential. Fractured basement covered $<30 \%$ of the study area. The evaluation of aquifer protective capacity has helped to classify the area into moderate, weak and poor protective capacities with moderate protective capacity zone covering $72 \%$.
\end{abstract}

${ }^{*}$ Corresponding author.

How to cite this paper: Ugwu, N.U., Ranganai, R.T., Simon, R.E. and Ogubazghi, G. (2016) Geoelectric Evaluation of Groundwater Potential and Vulnerability of Overburden Aquifers at Onibu-Eja Active Open Dumpsite, Osogbo, Southwestern Nigeria. Journal of Water Resource and Protection, 8, 311-329. http://dx.doi.org/10.4236/jwarp.2016.83026 


\section{Keywords}

\section{Southwestern Nigeria, Crystalline Rocks, Electrical Resistivity, Groundwater Potential, Vulnerability Mapping}

\section{Introduction}

The city of Osogbo and its environs in southwestern Nigeria are experiencing population growth and urbanization with its resultant pressure on the natural resources including both land and potable water supply. The state owned water board supplies water sourced and treated from the major river (River Osun). The water supply is grossly inadequate and some people rely on open surface water close to them. Groundwater that approximately 50 percent of the world's population uses every day [1] becomes another alternative means of water supply.

Osogbo area lies within the Precambrian basement complex terrain of southwestern Nigeria [2]. Exploration of groundwater in hard rock terrain is a very difficult task when the favorable groundwater zones are associated with fractured medium. In this environment, the groundwater potential hinges mainly on the thickness of the weathered/fractured layer overlying the basement [3]. According to [4], the overburden materials have high porosity, contain a considerable amount of water and exhibit low permeability due to its relatively high clay content. Aquifers in this basement terrain often occur at shallow depths, thus subjecting the water within to environmental hazard, susceptible to surface or near-surface contaminants. The major threat facing groundwater is pollution and degradation due to human activities, which has made fresh water scarce [5]. One of the most common sources of water pollution is dumpsites, whether landfill or open dump. Some dumpsites that were sited far from city centre are now being habited because of urbanizations. An example of such dumpsites is the Osun state main active open dump, Onibu-Eja Dumpsite, Osogbo (Figure 1(a) and Figure 1(b)) with residential buildings some few meters away.

The aim of this study is to use electrical resistivity method to delineate the groundwater aquifers, identify contamination zones and recommend appropriate points for groundwater abstraction. Electrical resistivity method using Vertical Electrical Sounding (VES) has been employed in groundwater over the years to characterize aquifers in different geologic environments and to map fractures in basement areas [6]-[10]. However, VES

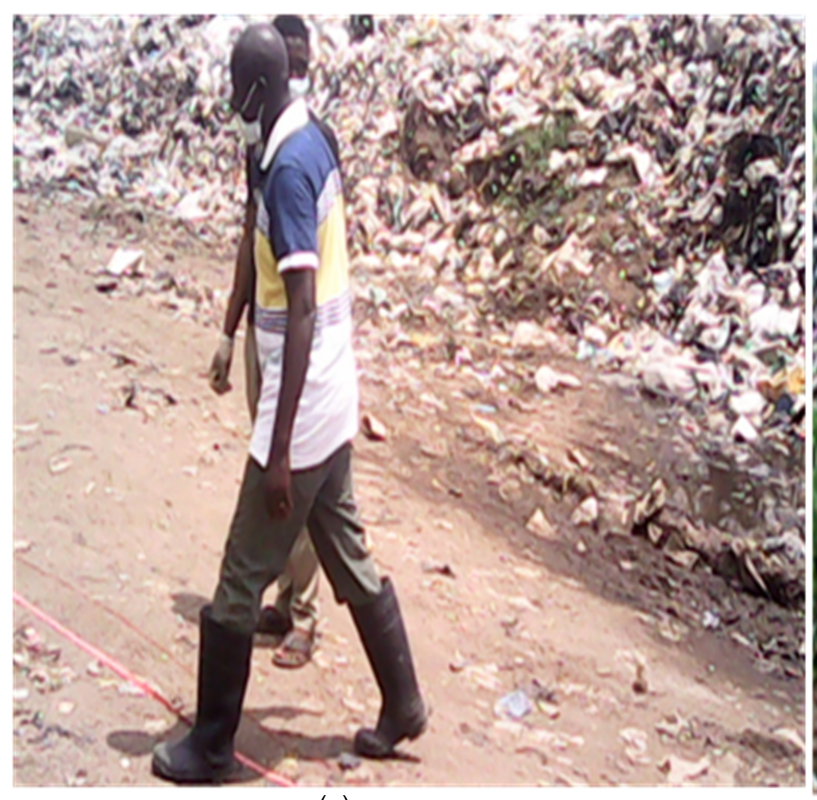

(a)

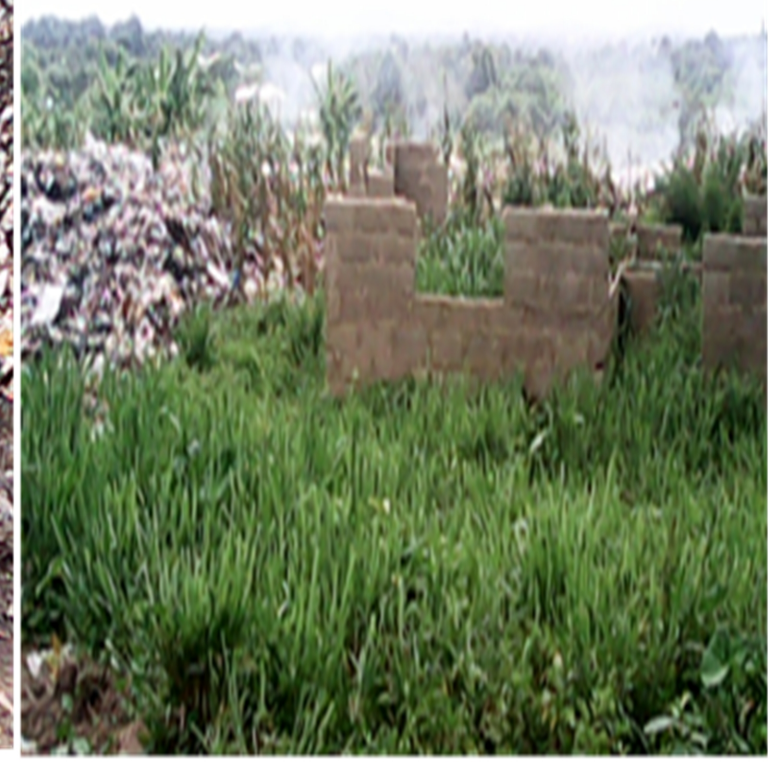

(b)

Figure 1. (a) A section of the Onibu-Eja active dumpsite and (b) an uncompleted house approximately $5.0 \mathrm{~m}$ distance from the dump which forms the problem associated with the site. 
produces 1-D model of the subsurface, which is not sufficient in mapping areas of complex subsurface geology. The basic sounding interpretation assumption of horizontally stratified earth model, which does not match the local geological model, is the major limitations of these methods [11]. The VES is complemented with Electrical Resistivity imaging which provides 2-D resistivity model of the subsurface, where resistivity changes in the vertical as well as in the lateral direction along the traverse are mapped continuously even in the presence of geological and topographical complexities [12]. 2D electrical resistivity imaging has been employed successfully in bedrock detection, geological mapping and groundwater investigation [13] [14].

\section{Study Location and Geology}

Osogbo is located between latitudes N07 $45.505^{\prime}$ and N07 $48.552^{\prime}$ and longitudes E04 $29.611^{\prime}$ and E04 $34.321^{\prime}$ (Figure 2(a)). The geology of the study area can be explained within the context of the geology of the Precambrian basement complex of southwestern Nigeria which form a part of the basement complex of Nigeria [2] [15]. The basement complex is one of the three major litho-petrological components that make up the geology of Nigeria. The major metamorphic rock types discovered around the study area, Osogbo, Southwestern Nigeria are quartzite and banded gneiss (Figure 2(a)). The quartzite found was highly fractured and outcrops as a massive ridge in the southern part of the area (Figure 2(b)). The mineralogy of the quartzite was mainly quartz with little mica. There were presences of various structures on the quartzite which include: fracture and foliation. The structures found in banded gneiss rocks were banding and joints. The joint strike directions are S172SE, E120SE, E120SE, E128SE, E110SE, and the dip $80^{\circ} \mathrm{NE}$. The area is part of Osogbo Metropolis and being a State capital has witnessed rapid growth in population. Figure 3 shows the base map of the active open dumpsite long Osogbo-Iwo highway. It was located using eTrex Legend, Garmin, Global Positioning System (GPS) with map datum at Minna, Nigeria. The X and $\mathrm{Y}$ axes show the easting and northing respectively. The dumpsite is accessible through a motorable path from the major highway. The dumping of waste started around 1992 and there was no engineering work on the site, which makes it purely an open surface dump. Although there is no record of the total tonnage of waste from inception, the estimated dimensions show that the dumpsite holds about 152 metric tons of waste. The area is characterized by many rivers flowing NW-SE and discharging into river Osun. The area is characterized by the tropical rain forest. The temperature ranges from $19^{\circ} \mathrm{C}$ to $34^{\circ} \mathrm{C}$ with an annual mean temperature of about $24^{\circ} \mathrm{C}$. The average rainfall is about $350 \mathrm{~mm}$ [16]. Leachate forms when rain falls and permeates through the waste dump, and can infiltrate across the unsaturated zone and transfer contaminated water to the aquifer.

\section{Materials and Method of Study}

Five traverses were established in W-E and S-N directions covering lateral distance between 105 to $240 \mathrm{~m}$ at the periphery of the dumpsite (Figure 3). The geophysical resistivity data was acquired with the Ohmega d. c. resistivity meter. Profile imaging, using dipole-dipole array, were surveyed along the traverses at inter-electrode spacing of $5 \mathrm{~m}$ and expansion factor (n) varied from 1 to 5 . The resulting apparent resistivity data was input into the DIPROFWIN software to obtain pseudosections. Inversions were run on the pseudosections to obtain theoretical data pseudosections and a $2 \mathrm{D}$ resistivity structure of the subsurface. The processed 2-D resistivity structure guided the location of vertical electrical sounding points. The Schlumberger array was adopted and eighteen VES points were carried out along the five traverses in W-E and S-N directions (Figure 3). The electrode spread of $\mathrm{AB} / 2$ was varied from 1 to $65 \mathrm{~m}$. The electrical resistivity data was processed by plotting the apparent resistivity values against the electrode spread $(\mathrm{AB} / 2)$. This was subsequently interpreted quantitatively using partial curve matching method [6] and computer assisted 1-D forward modelling with WinResist 1.0 version software [17]. Maximum information about the subsurface lithology and overburden thickness was generated.

The combination of the resistivity and thickness in the Dar Zarrouk parameter may be of direct use in aquifer vulnerability studies [18]. The aquifer protective capacity characterization is based on the values of the longitudinal unit conductance of the overburden rock units in the area. The longitudinal conductance $(S)$ of the overburden at each station was generated from the equation:

$$
S=\sum_{i=1}^{n} \frac{h_{i}}{\rho_{i}} .
$$

where $h_{i}$ is the layer thickness, $\rho_{i}$ is layer resistivity while the number of layers from the surface to the top of aquifer varies from $i=1$ to $n$. The various "randomly" distributed data were gridded at $10 \mathrm{~m}$ cell size (about half 

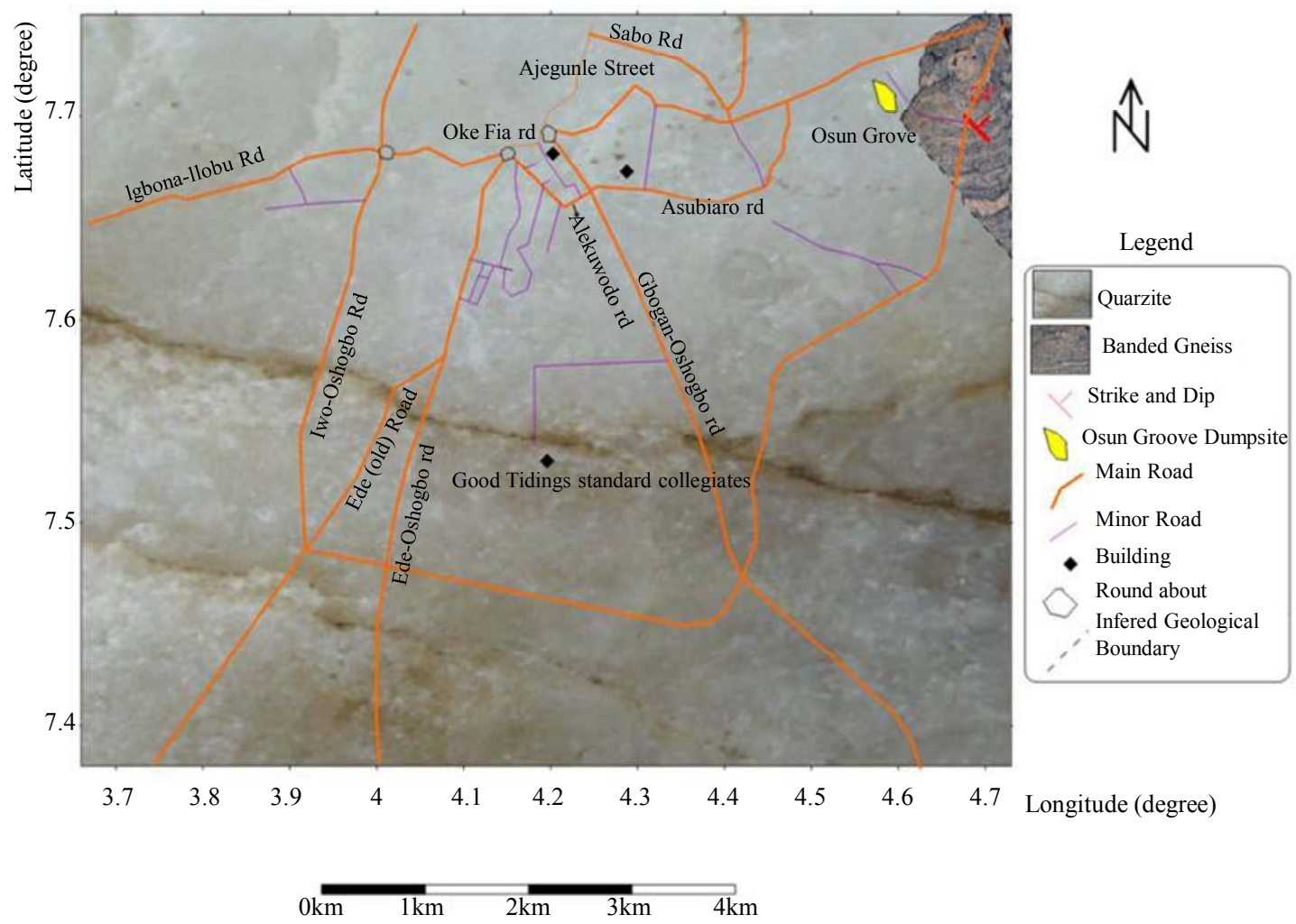

(a)

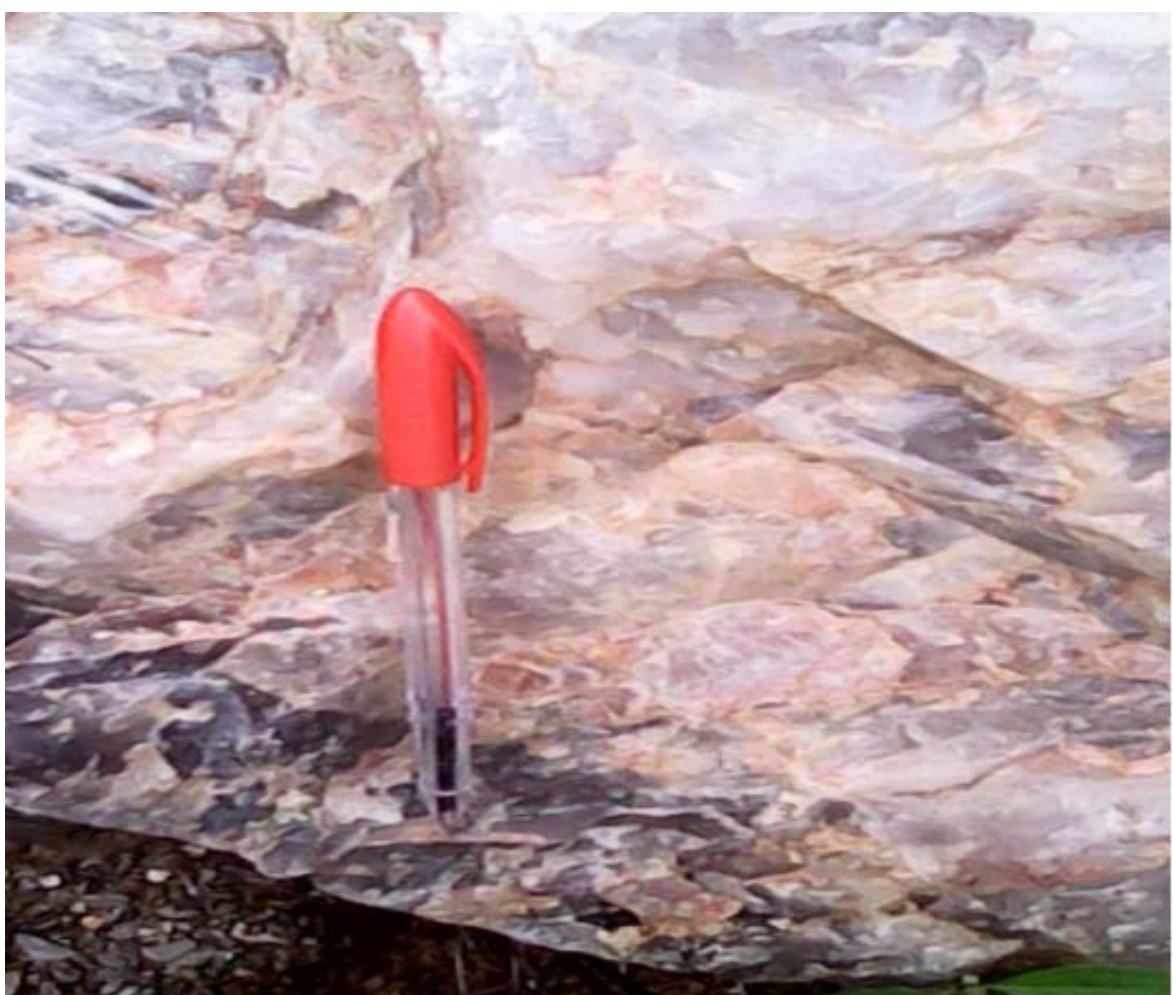

(b)

Figure 2. (a) The simplified geology map of the study area showing road network and some geological features; (b) A massive outcrop of quartzite with joints which is one of geological feature in the study area. 


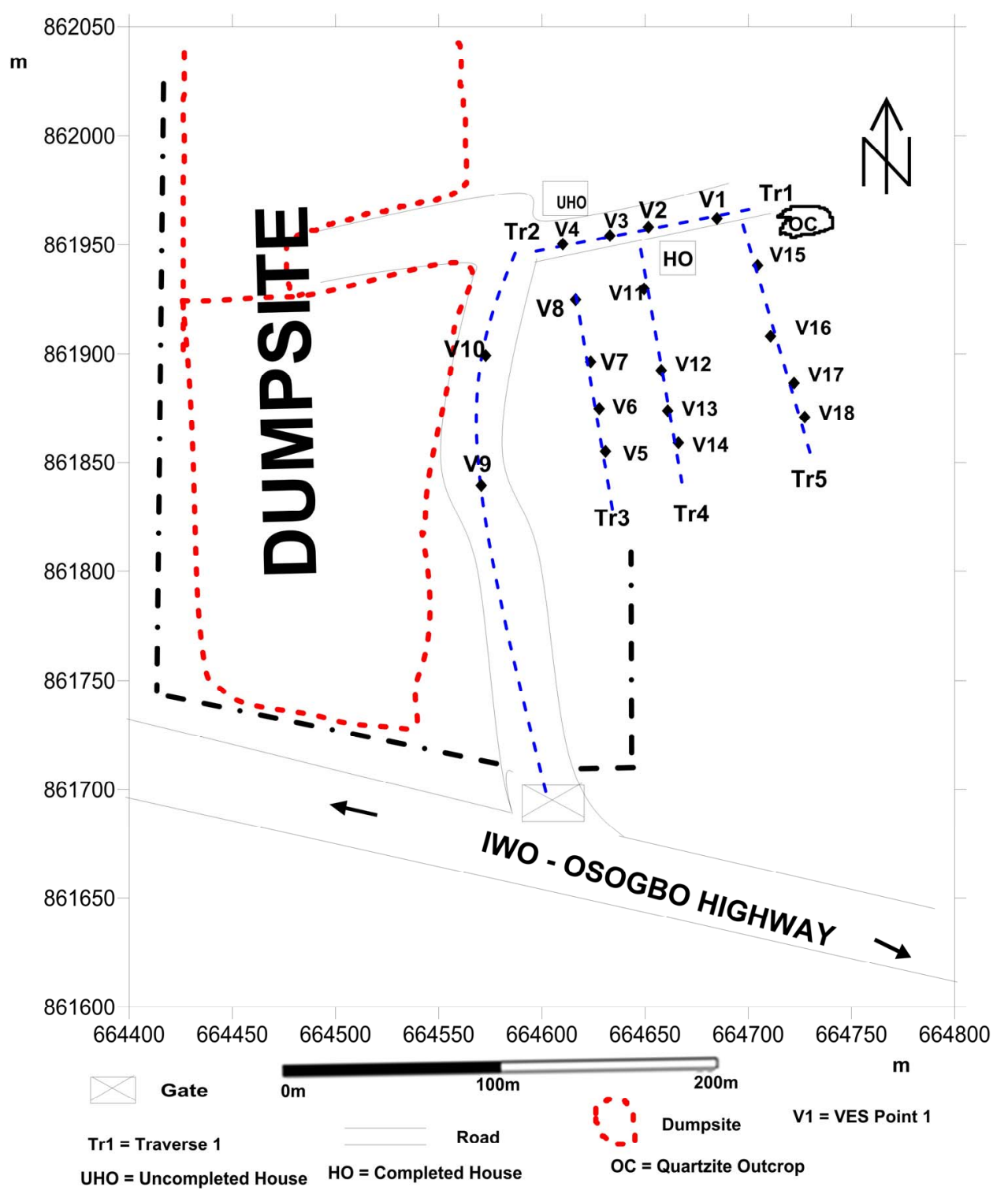

Figure 3. Data acquisition map of the study area showing locations of the traverses (Tr) and VES points $(\mathrm{V})$.

the nominal data point interval) in the universal traverse Mercator co-ordinate system using an iterative program based on the minimum curvature technique with tension [19]. Minimum curvature can cause undesired oscillations and false local maxima or minima, and use of tension $(\mathrm{T}>0)$ helps to suppress these effects. They were then contoured at different intervals depending on the variables.

\section{Result and Analyses}

The results are discussed under geoelectric sections, 2-D resistivity structure, and evaluation of groundwater potential in terms of overburden isopach map and isoresistivity maps and aquifer protective capacity (evaluation of aquifer vulnerability). The resistivity sounding curve-types acquired from the surveyed area range from 3-layer $(\mathrm{H})$ to 4-layer $(\mathrm{KH})$ or 5-layer $(\mathrm{HKH})$. Figure 4(a), Figure 4(b) are typical 1D resistivity curves of sampled VES stations showing observed apparent resistivity, calculated apparent resistivity and computed model. Summary of the formation of layer parameters and classification of the resistivity sounding curves is presented in Table 1. These type-curves, H, QH, KH and HKH can be interpreted in terms of the subsurface lithology (e.g. 


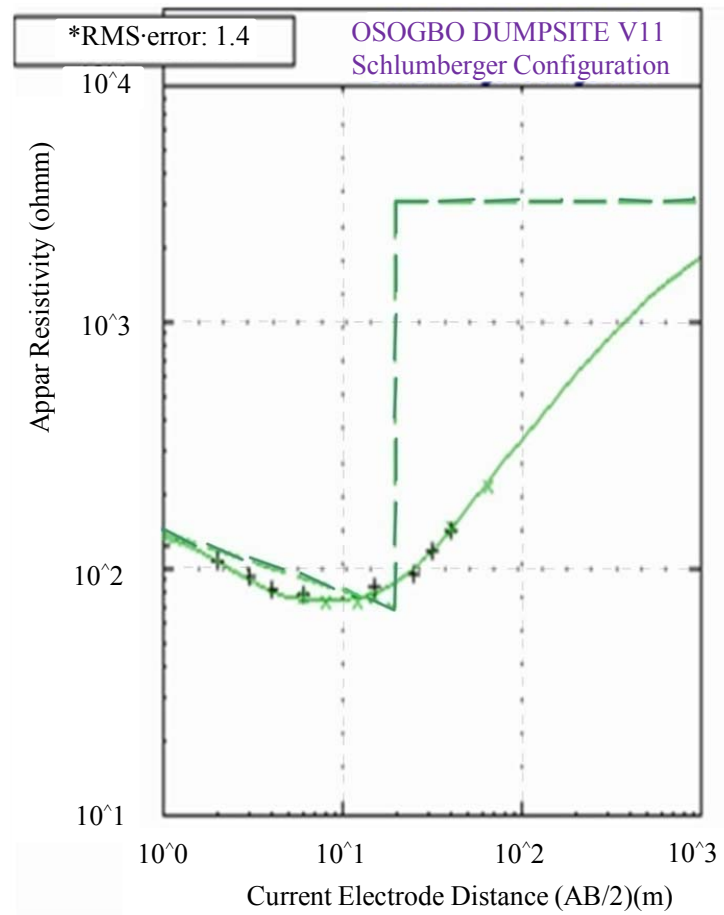

$$
\begin{array}{|llll}
\hline \multicolumn{3}{|c}{\text { No Res Thick Depth }} \\
\hdashline 1 & 143.4 & 0.9 & 0.9 \\
2 & 70.4 & 18.5 & 19.4 \\
3 & 3106.2 & \ddots & \ddots \\
\text { *RMS on smoothed data }
\end{array}
$$

$x \times x=$ Observed apparent resistivity

$-\ldots=$ Calculated apparent resistivity

$i^{-\cdots}$ Computed model

(a)

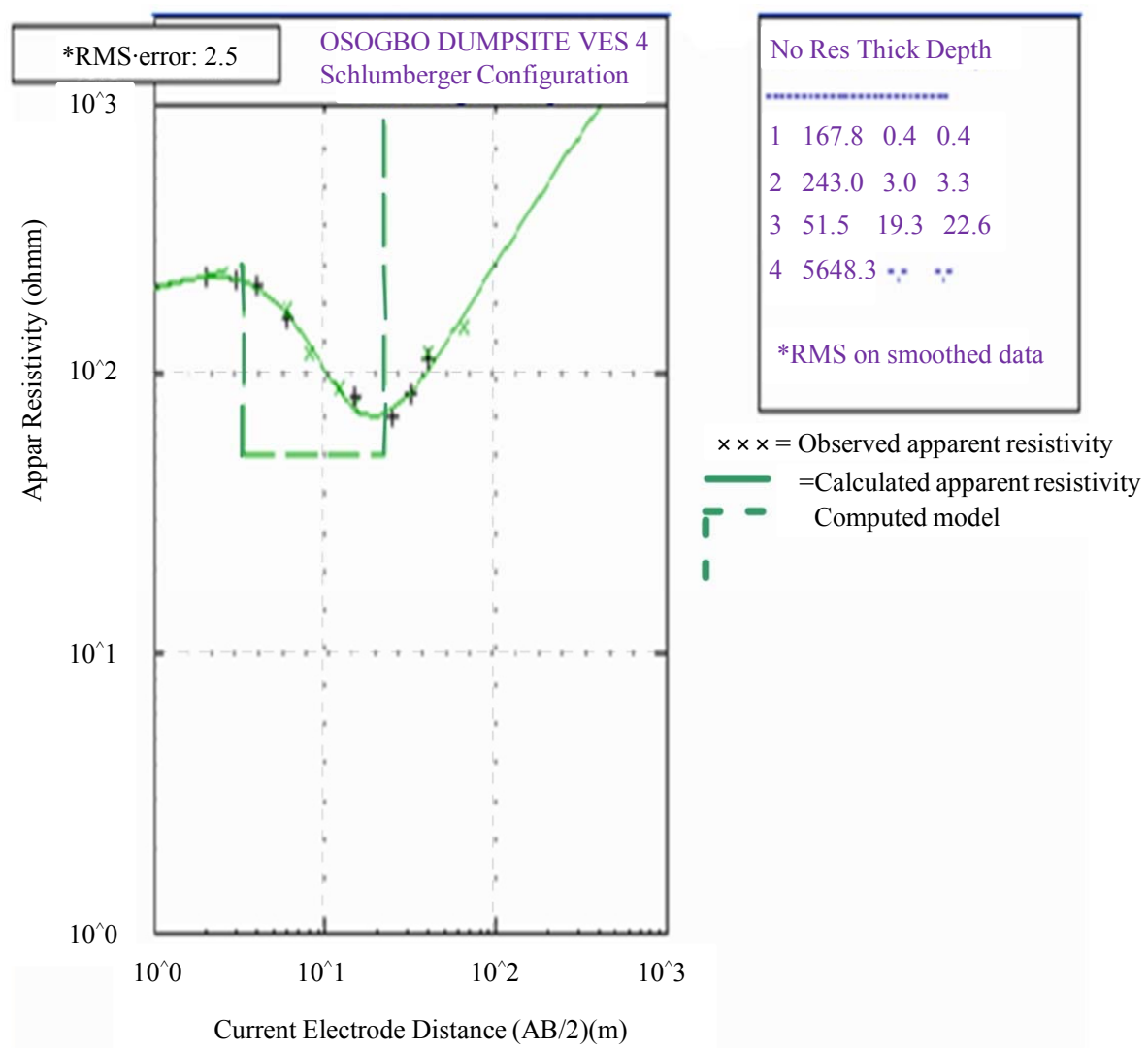

(b)

Figure 4. (a) Typical resistivity field curves of sampled VES stations showing H-curve; (b) Typical resistivity field curves of sampled VES stations showing KH-curve. 
Table 1. Summary of the geoelectric parameters over the study area.

\begin{tabular}{|c|c|c|c|c|c|c|c|c|c|c|c|c|c|}
\hline \multirow{2}{*}{$\begin{array}{l}\text { VES } \\
\text { NO }\end{array}$} & \multirow{2}{*}{$\begin{array}{l}\mathrm{NO} \text { of } \\
\text { layers }\end{array}$} & \multirow{2}{*}{$\begin{array}{l}\text { Curve } \\
\text { Type }\end{array}$} & \multicolumn{5}{|c|}{ Resistivity of layer $(\Omega \mathrm{m})$} & \multicolumn{4}{|c|}{ Thickness of layers (m) } & \multirow{2}{*}{$\begin{array}{c}\text { Depth to } \\
\text { basement }\end{array}$} & \multirow{2}{*}{$\begin{array}{l}\text { Longitudinal } \\
\text { conductance } \\
\text { (mhos) }\end{array}$} \\
\hline & & & $\rho_{1}$ & $\rho_{2}$ & $\rho_{3}$ & $\rho_{4}$ & $\rho_{5}$ & $h_{1}$ & $h_{2}$ & $h_{3}$ & $h_{4}$ & & \\
\hline 1 & 4 & $\mathrm{QH}$ & 805 & 333 & 54 & 398 & & 0.5 & 1.6 & 9.1 & & 11.2 & 0.174 \\
\hline 2 & 4 & $\mathrm{KH}$ & 179 & 258 & 136 & 16213 & & 0.4 & 6.0 & 24.2 & & 30.6 & 0.203 \\
\hline 3 & 5 & $\mathrm{HKH}$ & 119 & 73 & 271 & 31 & 6555 & 0.4 & 3.7 & 4.4 & 13.6 & 22.1 & 0.509 \\
\hline 4 & 4 & $\mathrm{KH}$ & 168 & 243 & 52 & 5648 & & 0.4 & 3.0 & 19.3 & & 22.7 & 0.386 \\
\hline 5 & 4 & $\mathrm{QH}$ & 127 & 108 & 49 & 7182 & & 0.5 & 7.9 & 19.2 & & 27.6 & 0.468 \\
\hline 6 & 5 & HKH & 161 & 78 & 212 & 54 & 7107 & 0.5 & 2.8 & 3.4 & 27.0 & 33.7 & 0.555 \\
\hline 7 & 4 & $\mathrm{KH}$ & 97 & 161 & 62 & 8618 & & 0.5 & 5.1 & 22.5 & & 28.1 & 0.400 \\
\hline 8 & 5 & HKH & 227 & 91 & 210 & 47 & 2824 & 0.6 & 3.5 & 3.8 & 14.6 & 22.5 & 0.370 \\
\hline 9 & 4 & $\mathrm{KH}$ & 114 & 151 & 43 & 4993 & & 0.4 & 2.8 & 24.0 & & 27.2 & 0.580 \\
\hline 10 & 4 & $\mathrm{KH}$ & 65 & 69 & 65 & 5128 & & 0.5 & 3.2 & 19.8 & & 23.5 & 0.359 \\
\hline 11 & 3 & $\mathrm{H}$ & 143 & 70 & 3106 & & & 0.9 & 18.5 & & & 19.4 & 0.271 \\
\hline 12 & 3 & $\mathrm{H}$ & 132 & 44 & 245 & & & 1.0 & 9.0 & & & 10.0 & 0.212 \\
\hline 13 & 5 & $\mathrm{HKH}$ & 219 & 52 & 161 & 54 & 1593 & 0.5 & 3.1 & 4.9 & 16.5 & 25.0 & 0.398 \\
\hline 14 & 3 & $\mathrm{H}$ & 299 & 83 & 2581 & & & 0.7 & 23.9 & & & 24.6 & 0.290 \\
\hline 15 & 4 & $\mathrm{HK}$ & 269 & 57 & 252 & 39 & & 0.5 & 6.5 & 9.8 & & 16.8 & 0.155 \\
\hline 16 & 4 & HK & 280 & 63 & 579 & 145 & & 0.5 & 1.2 & 6.0 & & 7.7 & 0.031 \\
\hline 17 & 4 & HK & 755 & 176 & 523 & 240 & & 0.6 & 2.1 & 4.2 & & 6.9 & 0.021 \\
\hline 18 & 4 & HK & 998 & 126 & 1253 & 36 & & 0.8 & 6.3 & 3.0 & & 10.1 & 0.053 \\
\hline
\end{tabular}

[20] [21]) and are often associated with groundwater possibilities [22]. The nature of the lithologic sequence in a place can be used in qualitative sense to evaluate the groundwater prospect of an area [23].

\subsection{Geoelectric Sections}

The interpreted VES results were used to prepare 2-D geoelectric sections which show respective layer resistivity values and thicknesses (Figures 5(a)-(d)). The sections were prepared according to the number of VES points in each traverse. It helps to see clearly where there is thin overburden as well as thick overburden within the sounding locations. The geoelectric sections presented showed three-to-five subsurface layers which include the topsoil, clay/weathered layer, partly weathered basement/weathered basement and fractured/fresh basement.

A maximum of three-to-five subsurface geoelectric units were delineated beneath VES points along traverse TR1 (Figure 5(a)). These include the topsoil (resistivity and thickness range of 119 to $805 \Omega \mathrm{m}$ and 0.4 to $0.5 \mathrm{~m}$ respectively) which overlies the weathered layer which has resistivity and thickness which vary from 243 to 333 $\Omega \mathrm{m}$ and 1.6 to $6.0 \mathrm{~m}$ respectively. The weathered layer is indicative of sand. Clay with resistivity value of 73 $\Omega \mathrm{m}$ and thickness of $3.7 \mathrm{~m}$ was delineated under VES point 3. The weathered basement has unsaturated clay/ sandy clay of resistivity between 31 and $136 \Omega \mathrm{m}$ and thickness between 4.4 and $24.2 \mathrm{~m}$. The weathered layer/ basement constitutes the groundwater aquifer with total thickness range between $10.7 \mathrm{~m}$ and $30.2 \mathrm{~m}$. A fractured basement with resistivity of $398 \Omega \mathrm{m}$ is delineated at VES point 1 and is favourable for groundwater. The most promising locations beneath this traverse are VES point 3 (approximately $58.0 \mathrm{~m}$ away from dumpsite) that has $3.7 \mathrm{~m}$ thick clay which could prevent leachate from permeating into the $18.0 \mathrm{~m}$ thick groundwater aquifer and VES point 1 (approximately $103 \mathrm{~m}$ away from dumpsite) which has lateritic topsoil that prevents run off pollutant from the dumpsite that could seep into the aquifer.

The geoelectric section B-B' delineated four to five distinct geoelectric layers along traverse TR3 about 28.0 $\mathrm{m}$ away from the dumpsite (Figure 5(b)). Resistivity and thickness values in these layers range from 97 to 227 $\Omega \mathrm{m}$ and 0.5 to $0.6 \mathrm{~m}$ for the topsoil; clay (VES points 6 and 8 ) with resistivity of 78 and $91 \Omega \mathrm{m}$ and thickness of 2.8 and $3.5 \mathrm{~m} ; 108$ to $212 \Omega \mathrm{m}$ and 3.4 to $7.9 \mathrm{~m}$ for the unconsolidated sandy clay/clayey sand sub-stratum, while the resistivity and thickness of the weathered basement varies from 47 to $62 \Omega \mathrm{m}$ and 9.2 to $27.0 \mathrm{~m}$. The 

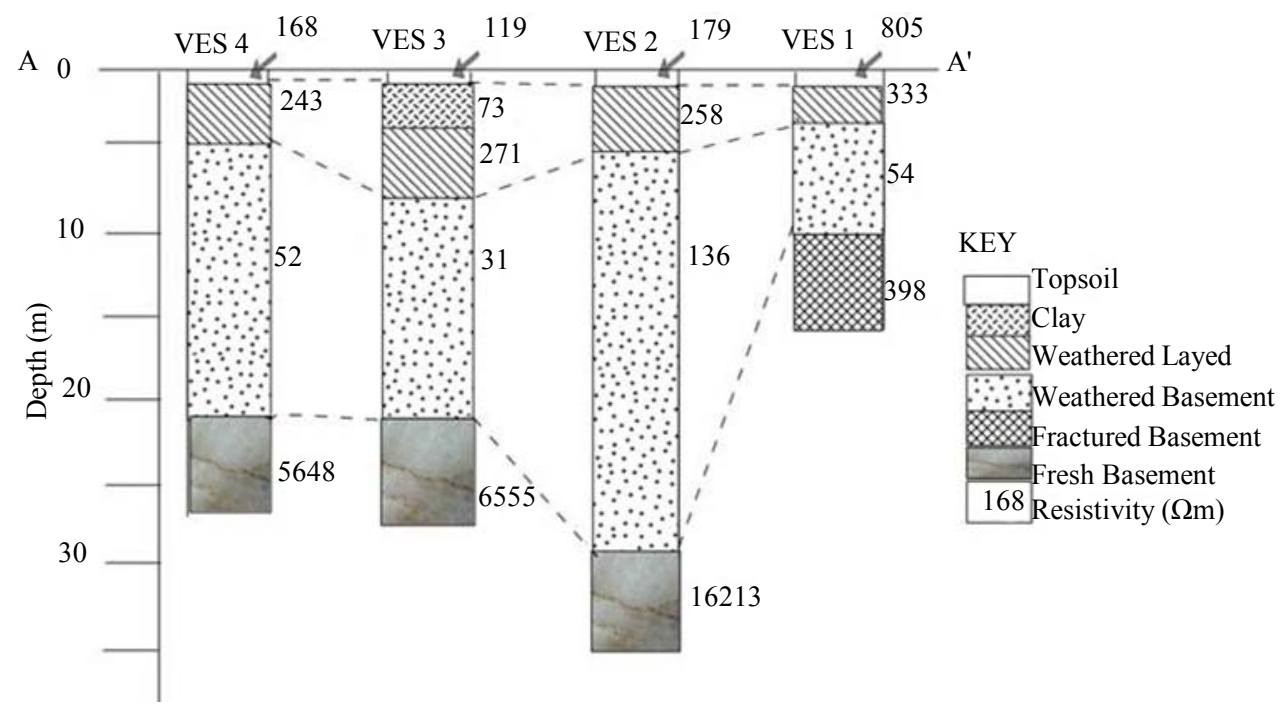

(a)

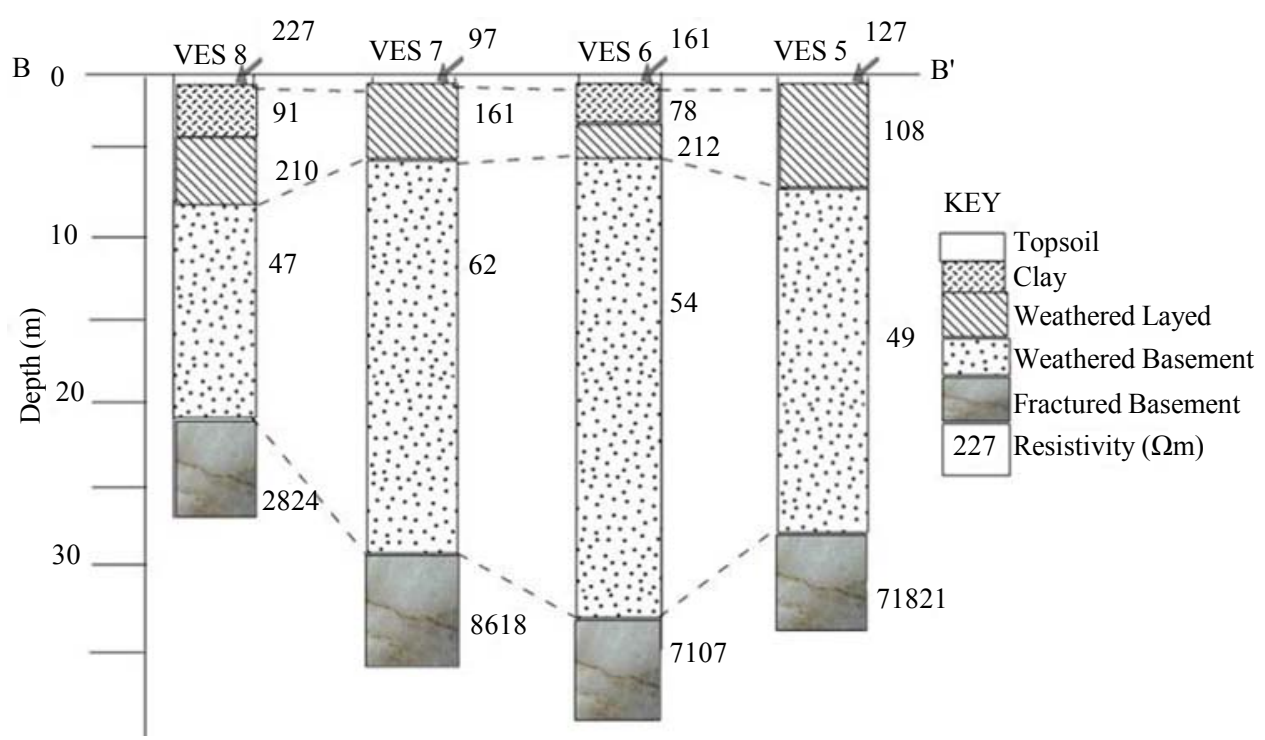

(b)

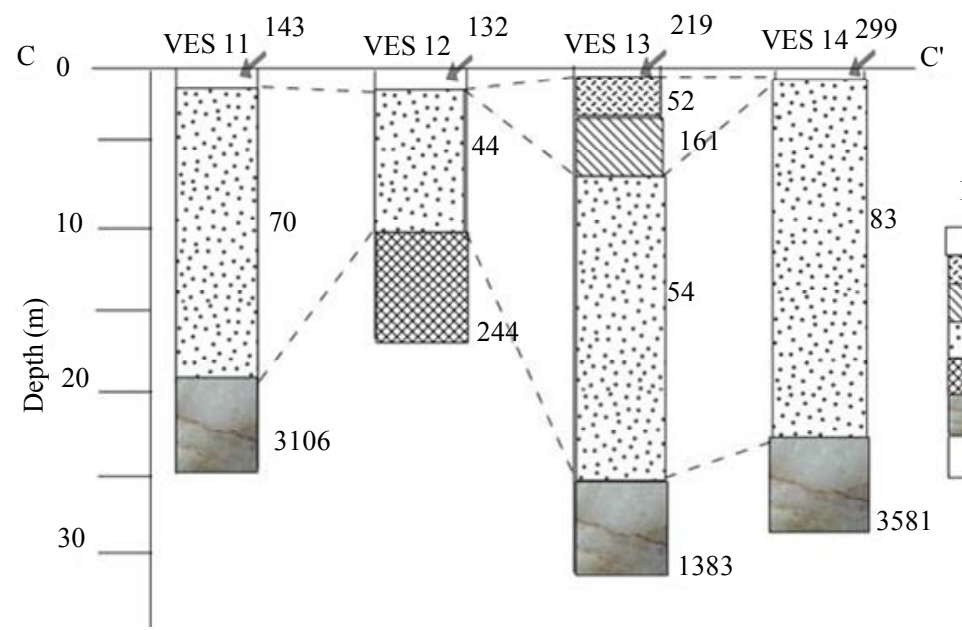

KEY

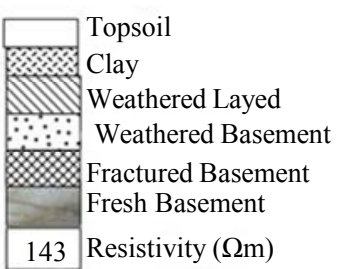

(c) 


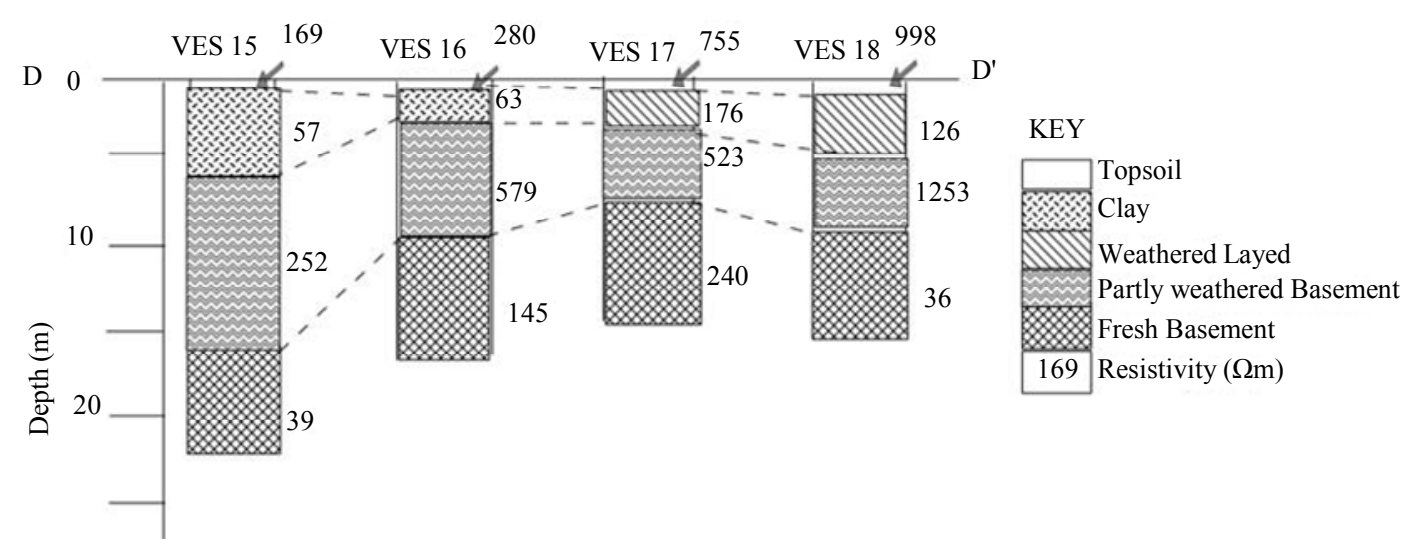

(d)

Figure 5. (a) Geoelectric sections along traverse TR1 comprising VES points V1-V4; (b) Geoelectric sections along traverse TR3 comprising VES points V6-V8; (c) Geoelectric sections along traverse TR4 comprising VES points V11-V14; (d) Geoelectric sections along traverse TR5 comprising VES points V15V18.

weathered layer and weathered basement constitute the groundwater aquifer with highest thickness of $27.0 \mathrm{~m}$ at VES point 6 . The fresh basement has resistivity which varies from 2824 to $8618 \Omega \mathrm{m}$. The proximity of this traverse to dumpsite makes the aquifer more vulnerable to contamination. However, VES points 6 and 8 could be considered as promising location for groundwater because of the presence of clay with thickness $2.8 \mathrm{~m}$ and 3.5 $\mathrm{m}$ respectively which shields the aquifer.

The geoelectric section C-C' along traverse TR4 about $53 \mathrm{~m}$ away from the dumpsite consists of three to five subsurface geologic layers (Figure 5(c)). These include the topsoil, the clay/weathered layer with resistivities and thickness ranging from 52 to $161 \Omega \mathrm{m}$ and $3.1 \mathrm{~m}$ and $4.9 \mathrm{~m}$; weathered basement (low resistivity varies from 44 to $83 \Omega \mathrm{m}$ and thickness ranges from 9.0 to $23.9 \mathrm{~m}$ ). Fresh bedrock was delineated under VES 11, VES 13 and VES 14 while VES 12 showed fractured bedrock.

In traverse TR 5, about $103 \mathrm{~m}$ away from the dumpsite, the geoelectric section D-D' has a maximum of four subsurface layers (Figure $5(\mathrm{~d})$ ). These include the topsoil (clayey sand/laterite) with resistivity and thickness varying from 280 to $998 \Omega \mathrm{m}$ and 0.5 to $0.8 \mathrm{~m}$ respectively which lies above the water table. Clay with resistivity between 57 and $63 \Omega \mathrm{m}$ and thickness between 1.2 and $6.5 \mathrm{~m}$ was delineated at VES point 15 and 16 while weathered layer (resistivity and thickness vary from 128 to $176 \Omega \mathrm{m}$ and from 2.1 to $6.3 \mathrm{~m}$ ) is seen at VES point 17 and 18. A partly weathered basement with resistivity and thickness varying between 252 and $1253 \Omega \mathrm{m}$ and 3.0 and $9.8 \mathrm{~m}$ respectively is delineated overlying the fractured basement with resistivity range from 36 to $240 \Omega \mathrm{m}$.

\subsection{The 2-D Resistivity Structures Distribution}

The interpreted 2-D resistivity structure sections were merged to form a pseudo-3D pattern of the resistivity map of the study area. This arrangement of the resistivity sections makes it possible to observe the distribution trend of the resistivity pattern in the study area. The subsurface resistivity in the 2-D resistivity structure (Figure 6) shows a wide variation in the rock or lithology resistivity and at different depth along the profiles. The first two layers, the topsoil and weathered layer have resistivity value ranges between $30 \Omega \mathrm{m}$ and $1880 \Omega \mathrm{m}$ with thickness varying from $<2 \mathrm{~m}$ to about $10 \mathrm{~m}$. The subsurface resistivity heterogeneity comes from the existence of clayey sand/sandy clay with lateritic clay and outcrop at traverse TR1 to TR5. The weathered basement is mostly characterized by low resistivity value ranges between $5 \Omega \mathrm{m}$ and $100 \Omega \mathrm{m}$ while thickness varies from 10 to 20 $\mathrm{m}$. This is seen on part of profiles along traverse TR1 to TR3 which are closer to the dumpsite as indicated in Figure 6.

\subsection{Isopach and Isoresistivity Maps of Aquifer Units in the Area}

The isopach and isoresistivity maps of the study area are shown (Figure 7 and Figure 8). The thickness of the overburden and the resistivity are important hydrogeologic considerations in groundwater development in the 


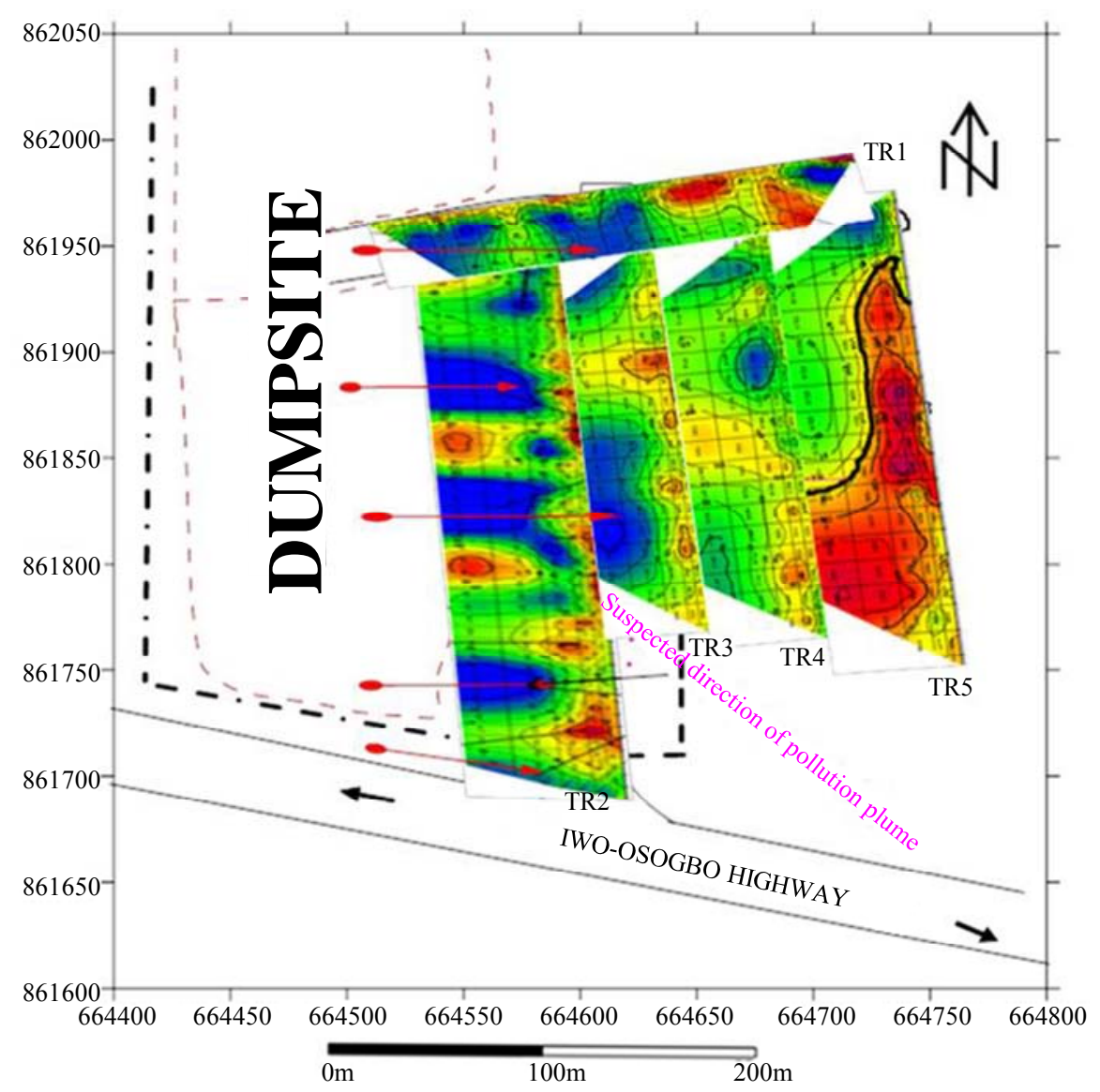

Figure 6. The 2-D resistivity structures distribution showing low resistivity zones suspected to be pollution plume.

basement terrain. The reason for this is that water gets into the saturated zone through the overburden.

\subsubsection{Assessment of Groundwater Potential in Terms of Overburden Thickness.}

Depth to fresh basement (overburden thickness) at each VES sounding station was gridded and contoured and shown as isopach map of the overburden (Figure 7). The overburden include the topsoil, weathered layer and partly/weathered basement. The depth to fresh basement varies from 6.9 to $33.7 \mathrm{~m}$. Generally, the overburden thickness is trending N-S and high overburden thickness is observed near the dumpsite and low farthest away. The map has been subdivided into four zones of high (A); medium (B); low (C) and minimal (D) groundwater potential. In Figure 7 zone A shows that overburden thickness $<40 \mathrm{~m}$ has $11 \%$, zone B with overburden thickness $<30 \mathrm{~m}$ which is the most predominant occupies $50 \%$ while $28 \%$ overburden thickness for zone $\mathrm{C}$ is $<20 \mathrm{~m}$. the percentage of overburden thickness $<10 \mathrm{~m}$ at zone $\mathrm{D}$ is $11 \%$.

\subsubsection{Assessment of Groundwater Potential Using Isoresistivity Maps}

\section{1) Isoresistivity map of weathered layer}

The groundwater potential could also be zoned into high, medium and low potential based on weathered layer resistivity. The isoresistivity map of the weathered layer is shown in Figure 8(a). Zones where resistivity is $<100 \Omega \mathrm{m}$ is classified as low groundwater potential, zone where resistivity ranges from 100 to $250 \Omega \mathrm{m}$ is classified as medium groundwater potential while zones with resistivity $>250 \Omega \mathrm{m}$ are classified as high groundwater potential [21]. This partly or generally correlates with the overburden thickness map (Figure 7).

The weathered layer resistivity values vary from 63 to $333 \Omega \mathrm{m}$. The study area is dominated by zone of medium groundwater potential (100 to $250 \Omega \mathrm{m}$ ). This zone is interpreted to be made of sandy clay/clayey sand. Zone of low groundwater potential $(<100 \Omega \mathrm{m})$ has impermeable clay materials. a porous and permeable sand is 


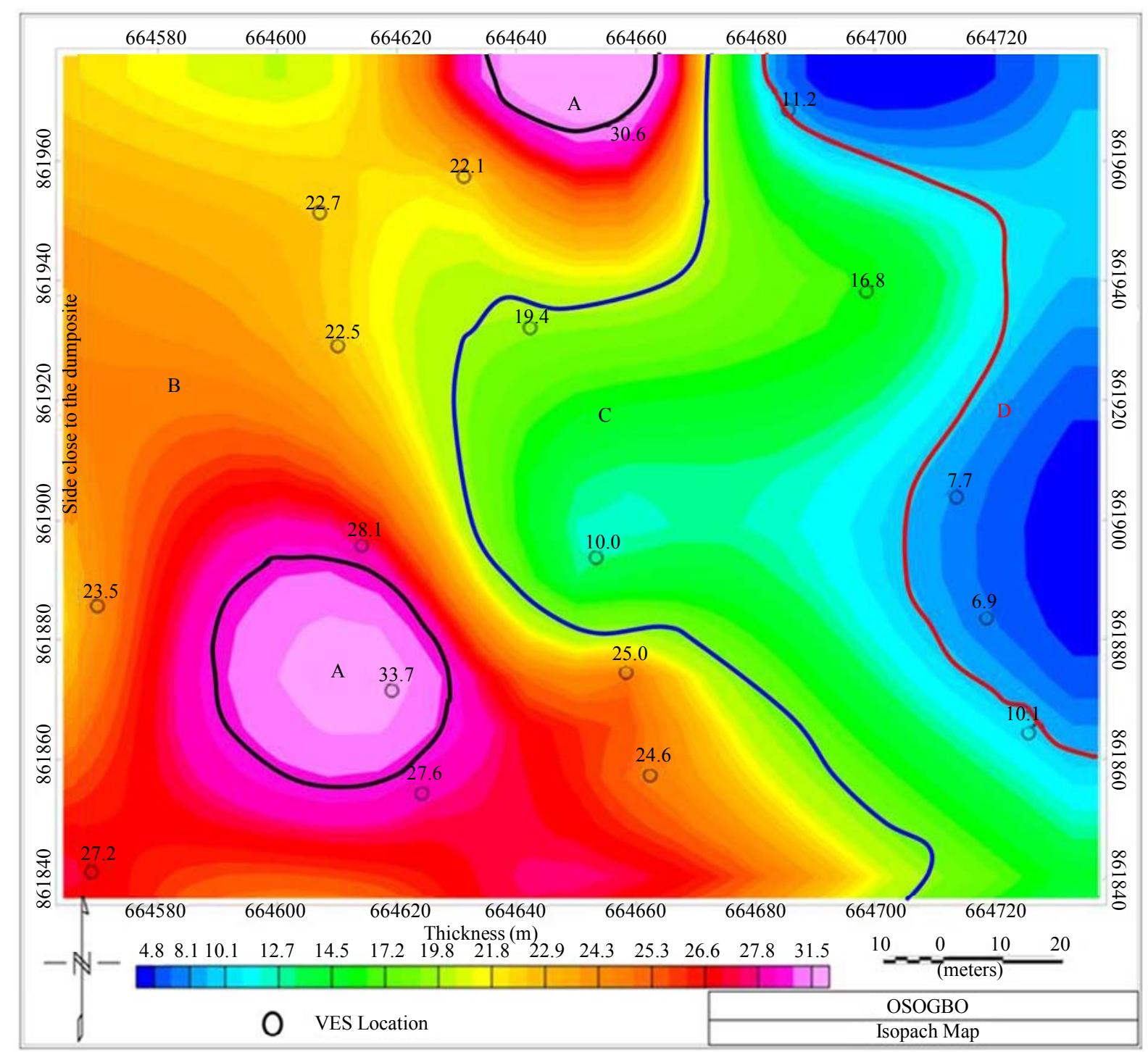

Figure 7. Isopach map of the overburden thickness in the study area. Almost half the area has the optimum thickness $(<30$ $\mathrm{m})$.

indicated as zone of high groundwater potential with resistivity $>250 \Omega \mathrm{m}$.

\section{2) Isoresistivity map of weathered basement}

The resistivity values of weathered basement at the various VES stations occupied in the study area were contoured and presented as isoresistivity map of weathered basement (Figure 8(b)). The resistivity values range from 31 to $1253 \Omega \mathrm{m}$. This indicates that the material composition is largely clay/sandy clay/clayey sand [24][26].

[27] [28] developed a scheme for ranking of groundwater potential as a function of saprolite (weathered basement) resistivity as presented in Table 2 . This classification shows that resistivity range $20-100 \Omega \mathrm{m}$ is related with optimum weathering and groundwater potential while resistivity range of $101-150 \Omega \mathrm{m}$ are suggestive of medium aquifer conditions and potential. When the weathered basement resistivity falls within the range of $151-300 \Omega \mathrm{m}$, it is indicative of limited weathering and poor potential. By this classification, $72 \%$ of the study area (Figure 8(b) and Figure 9) is characterized by optimum weathering and groundwater potential with $5.5 \%$ of the study showing medium aquifer conditions and potential. Also $5.5 \%$ account for areas of limited weathering and poor potential. The weathered basement resistivity values $>300 \Omega \mathrm{m}$ represents $17 \%$. This region offers no appeal for groundwater development unless it is overlain by thick overburden. Region of the map that 


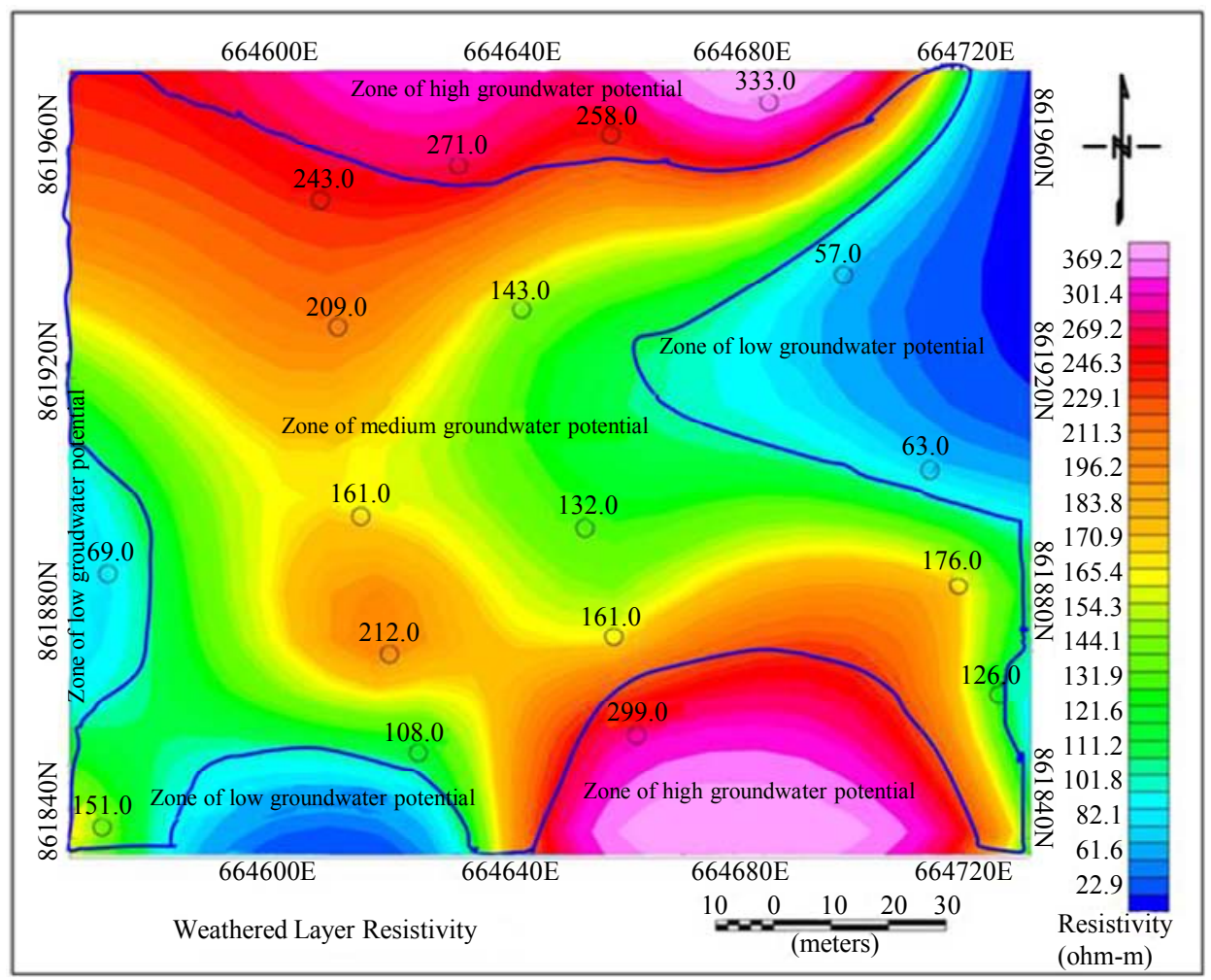

(a)

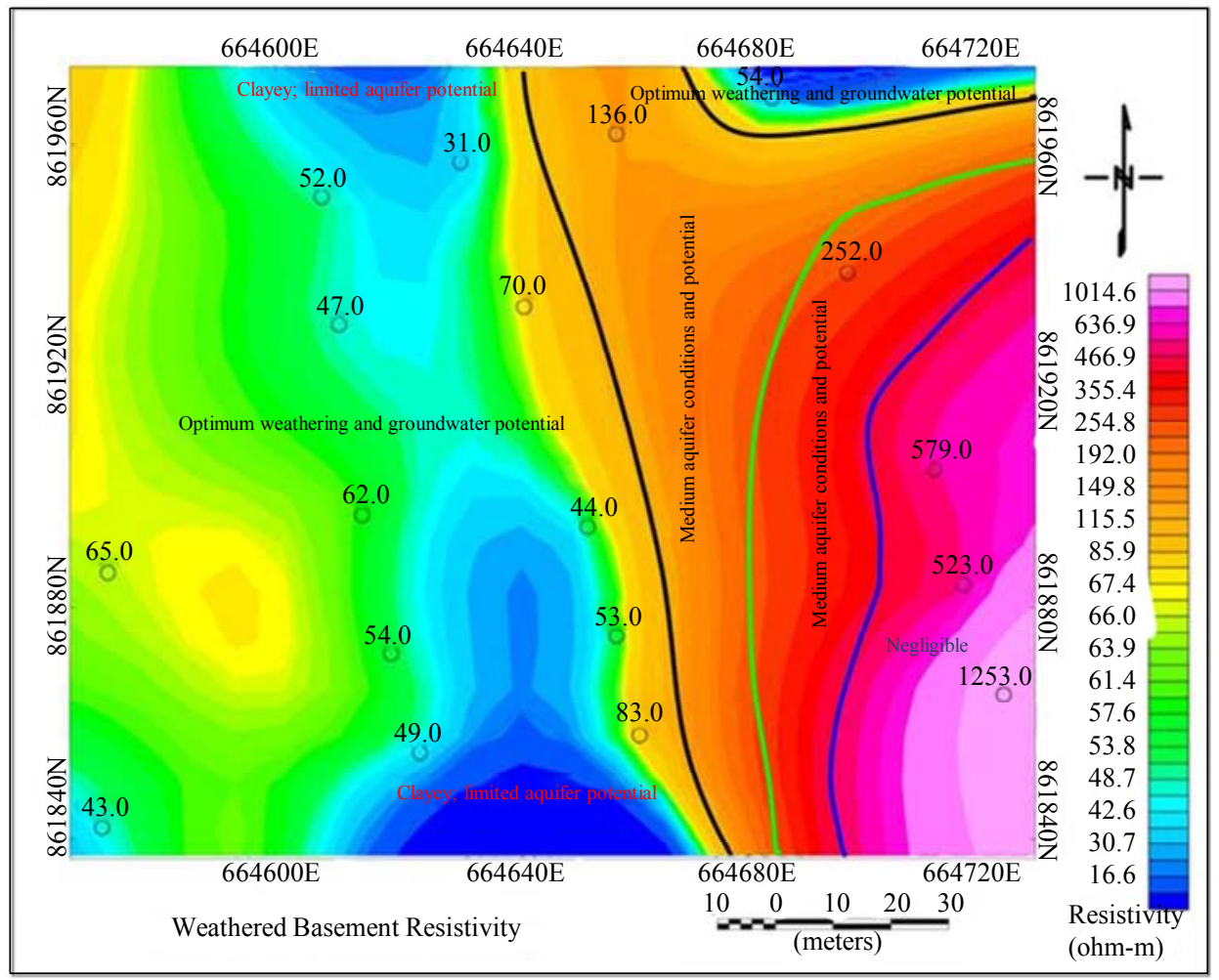

(b)

Figure 8. (a) The weathered layer resistivity distribution map of the study area; (b) The weathered basement resistivity distribution map of the study area. 
Table 2. Aquifer potential as a function of saprolite resistivity of the study area.

\begin{tabular}{cc}
\hline Saprolite resistivity $(\Omega \mathrm{m})$ & Aquifer characteristics \\
$<20$ & Clayey; limited aquifer potential \\
$20-100$ & Optimum weathering and groundwater potential \\
$101-150$ & Medium aquifer conditions and potential \\
$151-300$ & Limited weathering and poor potential \\
$>300$ & Negligible \\
\hline
\end{tabular}

Source: Modified after [27] [28].

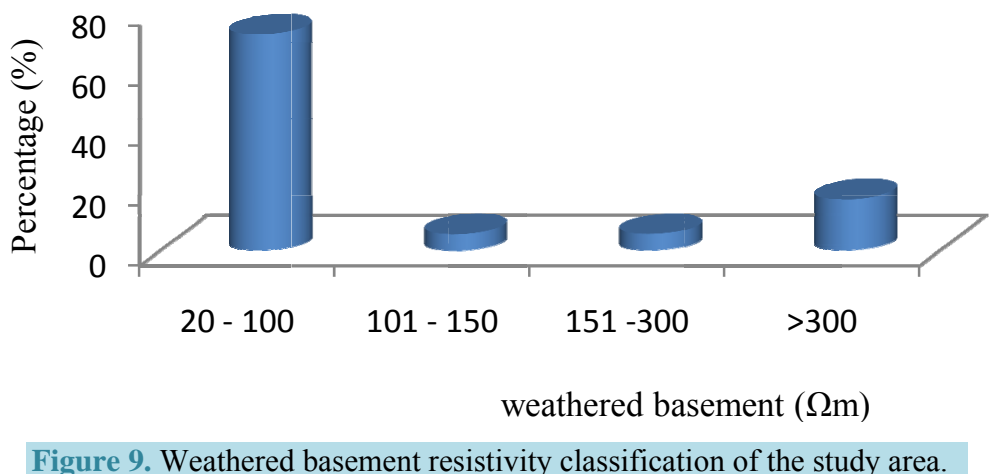

falls into clayey formation with resistivity $<20 \Omega \mathrm{m}$ has limited aquifer potential. Again, general classifications agree with the previous overburden thickness (Figure 7) and weathered layer resistivity (Figure 8(a)) assessments.

\subsection{Bedrock Resistivity Distribution Map of the Study Area}

Aquiferous units in the basement complex terrain are mainly found in the thick and porous weathered overburden (saprolite zone) and the fractured part of the bedrock. The presence of these fractures further supports the groundwater potentials of those zones [26] [29] [30]. Fractures influence the groundwater yield more than weathered layer probably because of the relatively high permeability [31]-[33]. A modified aquifer potential as a function of the fractured bedrock is shown in Table 3. The fractured/fresh bedrock resistivity values of the study area vary from $36-16,213 \Omega \mathrm{m}$ (Figure 10). High fractured permeability as a result of weathering is delineated at the eastern part with resistivity values $<750 \Omega \mathrm{m}$, an indication of high aquifer potential. Fairly low effect of fractures is noted at the central area within resistivity range of $1501-3000 \Omega \mathrm{m}$; thus exhibiting low aquifer potential. Over $55 \%$ of the area is underlain by fresh basement rocks with resistivities $\geq 3106 \Omega \mathrm{m}$ and this is seen at the western area, also extending to the north and south. These areas show little or no fractured bedrock; thus they have negligible aquifer potential.

\subsection{Evaluation of Aquifer Protective Capacity}

Aquifer protective capacity (APC) is the ability of the overburden unit to impede and filter percolating ground surface leaching fluid from entering into the aquiferous unit [35]. The aquifer protective capacity characterization is based on the values of the longitudinal unit conductance of the overburden rock units in the area. The longitudinal unit conductance $(S)$ values obtained from the study area range from 0.021 to 0.580 mhos and were used to generate the map shown in Figure 11. Clayey overburden, which is depicted by relatively high longitudinal conductance, gives protection to the underlying aquifer. [36]-[38] classified the protective capacity of the overburden into excellent, very good, good, moderate, weak and poor protective capacity zones (Table 4). The portion having conductance values ranging from 0.2 to 0.69 mhos covered about $72 \%$ of the study area and was classified as zone of moderate protective capacity; the values between 0.1 and 0.19 mhos covered about $11 \%$ and was classified as of weak protective capacity and about $17 \%$ of the area has conductance value $<0.1 \mathrm{mhos}$ and was considered poor (Figure 11). 
Table 3. Aquifer potential as a function of the fractured bedrock

\begin{tabular}{cc}
\hline Saprolite resistivity $(\Omega \mathrm{m})$ & Aquifer characteristics \\
\hline 750 & $\begin{array}{c}\text { High fractured permeability as a result of weathering; } \\
\text { high aquifer potential. }\end{array}$ \\
$1501-3000$ & $\begin{array}{c}\text { Reduced influence of weathering; medium aquifer potential. } \\
\text { Fairly low effect of weathering; low aquifer potential. }\end{array}$ \\
$>3000$ & Little or no weathering of the bedrock; negligible aquifer potential. \\
\hline
\end{tabular}

Source: Modified after [28] [34].

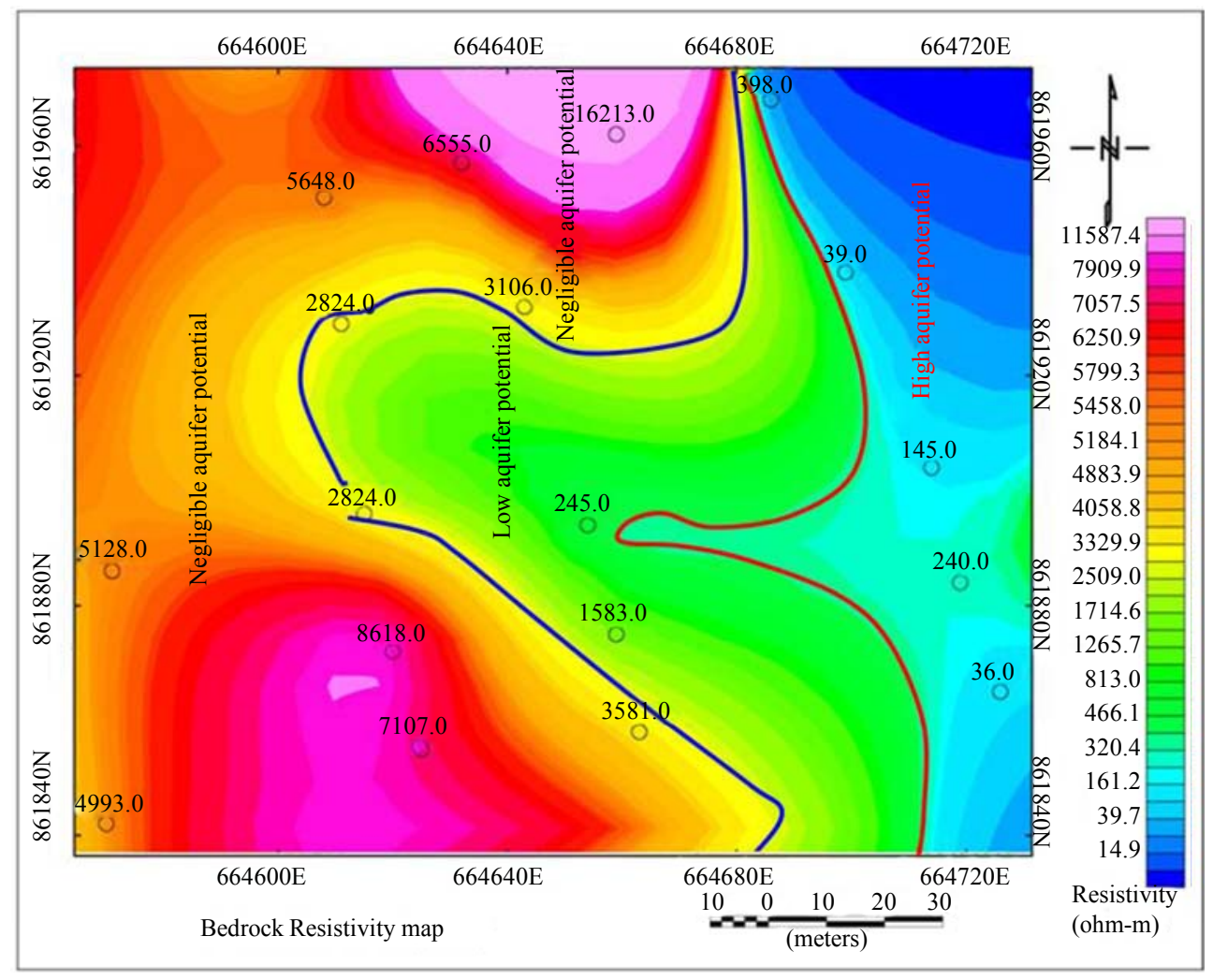

Figure 10. Bedrock resistivity distribution map of the study area.

\section{Discussion}

\subsection{Subsurface Resistivity and Lithology}

The geoelectric survey shows the form of subsurface resistivity variations around the dumpsite. A number of authors have attempted to correlate the typical geological sequence in basement complex terrain with resistivity ranges (e.g. [27] [34] [39]). On this basis, three to five subsurface geologic layers were delineated which include the topsoil, clay/weathered layer, weathered basement and fractured/fresh basement. The geoelectric sections showed topsoil of resistivity and thickness values varied from 65 to $998 \Omega \mathrm{m}$ and 0.4 to $1.0 \mathrm{~m}$; clay layer with resistivity and thickness values of range 52 to $91 \Omega \mathrm{m}$ and 1.2 to $6.5 \Omega \mathrm{m}$. The weathered layer depicted a heterogeneous subsurface of clay/sandy clay and clayey sand with resistivity and thickness values varying from 63 to $333 \Omega \mathrm{m}$ and 0.7 to $8.5 \mathrm{~m}$; weathered basement has resistivity of between $31 \Omega \mathrm{m}$ and $1253 \Omega \mathrm{m}$ and thickness between $3.0 \mathrm{~m}$ and $27.0 \mathrm{~m}$. The fractured/fresh basement showed resistivity values ranging from 36 to 16,213 $\Omega \mathrm{m}$.

In 2-D imaging the topsoil and the weathered layers show resistivity heterogeneities which come from the 


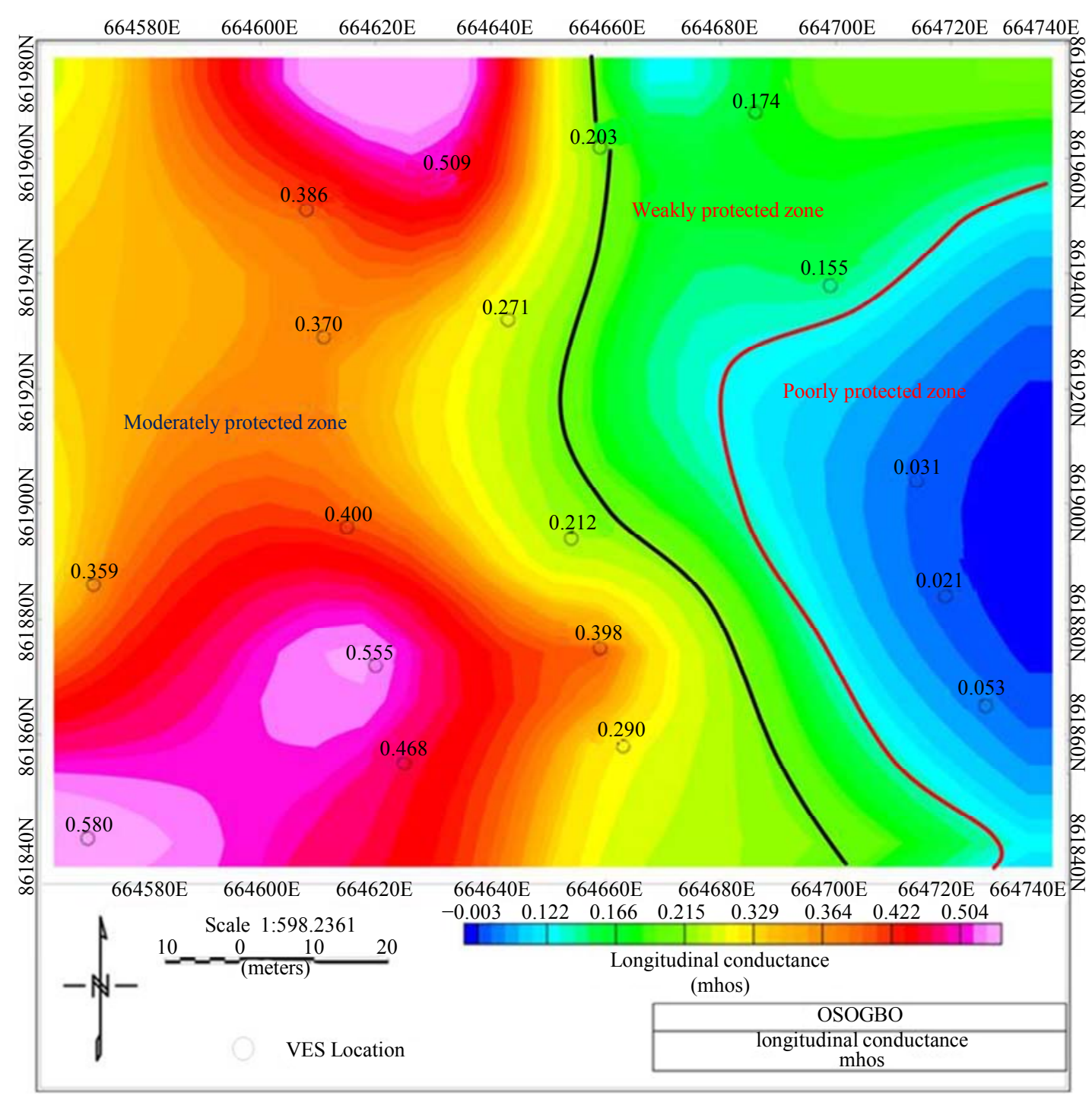

Figure 11. Spatial distributions of longitudinal conductance and aquifer protection capacity zones.

Table 4. Modified longitudinal conductance/protective capacity rating [36]-[38].

\begin{tabular}{cc}
\hline Longitudinal conductance (mhos) & Protective capacity rating \\
$>10$ & Excellent \\
$5-10$ & Very Good \\
$0.7-4.9$ & Good \\
$0.2-0.69$ & Moderate \\
$0.1-0.19$ & Weak \\
$<0.1$ & Poor \\
\hline
\end{tabular}

existence of clayey sand/sandy clay with lateritic clay along traverse TR1 to TR5. The resistivity value ranges between $30 \Omega \mathrm{m}$ and $1880 \Omega \mathrm{m}$ with thickness varying from $<2 \mathrm{~m}$ to about $10 \mathrm{~m}$. The weathered basement is mostly characterized by low resistivity value ranges between $5 \Omega \mathrm{m}$ to $100 \Omega \mathrm{m}$ while thickness varies from 10 to $20 \mathrm{~m}$. As mentioned earlier, the natures of the lithologic sequences, and the thickness and resistivity of overburden, are particularly important hydrogeologic considerations in assessing the groundwater potential of basement complex terrains. 


\subsection{Groundwater Potential}

[34] proposed values of overburden thickness ranging between $20 \mathrm{~m}$ and $30 \mathrm{~m}$ for productive wells in Shaki, west of the study area. Similarly, [36] [40] also prescribed a minimum overburden thickness of $25 \mathrm{~m}$ for viable groundwater abstraction in similar environments. In the surveyed area, the depth to fresh basement (total overburden) varies from 6.9 to $33.7 \mathrm{~m}$. Overburden thickness of between $20 \mathrm{~m}$ and $40 \mathrm{~m}$ occurred in $61 \%$ which thus suggests that the water-bearing horizon across the area is generally significantly thick and can support productive groundwater abstraction (Figure 7). In a comparable basement complex in Zimbabwe, [41] recommended a minimum of $10 \mathrm{~m}$ of regolith thickness to ensure sufficient yield.

According to [42] the thick weathered layer (containing less percentage of clay) above the basement rock constitutes a water-bearing layer. The weathered layer resistivity ranged between $63 \Omega \mathrm{m}$ and $333 \Omega \mathrm{m}$ with about $85 \%$ of the area falling within medium groundwater potential (100 to $250 \Omega \mathrm{m})$ and high groundwater potential $(>250 \Omega \mathrm{m})$ according to [21]. The weathered layer in the surveyed area can only support hand dug wells because the thickness ranges from 0.7 to $8.5 \mathrm{~m}$ (Figure 5) which conforms to average well depth of $7.07 \mathrm{~m}$ in the neighbouring residential settlements [16] [43]. The weathered basement resistivity values range from 31 to 1253 $\Omega \mathrm{m}$ with the thickness varying from 3.0 to $27.0 \mathrm{~m}$. The ranking of groundwater potential as a function of saprolite resistivity [27] [28] showed that $72 \%$ of the study area with 20 to $100 \Omega \mathrm{m}$ is characterized by optimum weathering and groundwater potential while $5.5 \%$ of the study area with resistivity between 101 and $150 \Omega \mathrm{m}$ exhibited medium aquifer conditions and potential. Bedrock fractures contribute substantially to groundwater yield in a typical basement complex area. High fractured permeability as a result of weathering is observed at the eastern part with resistivity values $<750 \Omega \mathrm{m}$ an indication of high aquifer potential. However, the fractured zone covered $<30 \%$ of the study area. It is significant that the three main important characteristics, namely overburden thickness, weathered layer resistivity and weathered basement resistivity generally support one another in the groundwater potential evaluation.

\subsection{Aquifer Vulnerability}

The low resistivity value materials suspected to be caused by leachate from the dumpsite are seen along traverses TR1 to TR3 closer to the dumpsite. This implies that contaminant leachate plume seeped to the bottom in vertical motion to the groundwater aquifer. [44] attributed the vertical motion to the relative porous and permeability of the sandy overburden in such affected zones. Thus the groundwater aquifer close to dumpsites is vulnerable to contamination, therefore it becomes imperative to evaluate and classify the aquifer protective capacity according to previous studies (e.g. [36]-[38]). The portion having conductance values ranging from 0.2 to 0.69 mhos covered about $72 \%$ of the study area and was classified as zone of moderate protective capacity; that ranging from 0.1 to 0.19 mhos covered about $11 \%$ and was classified as of weak protective capacity and about $17 \%$ of the area has conductance value $<0.1$ mhos and was considered poor. The weak and poor protective zones are prone to surface and near-surface leachate, while in the moderately protected zones, the aquifer is fairly protected from leachate percolating fluids. In the latter zones the topmost layers/weathered layer are mostly sandy, and where clays which protect the aquifer are found, they are usually very thin and hence provide little or no protection for the underlying aquifer.

\subsection{Correlation of Maps}

The 3D display in Figure 12 is a correlation of the various maps and helps to summarize the groundwater potential and the vulnerability of the aquifers (Table 5).

\section{Conclusion}

In conclusion, the factors discussed above have to be taken into consideration when sitting a hand dug well or borehole in the study area. It is, therefore, necessary that such VES position should have protective clay of thickness $>2.5 \mathrm{~m}$, productive overburden thickness ranging from 20 to $40 \mathrm{~m} \mathrm{[34]} \mathrm{[36]} \mathrm{[40],} \mathrm{and} \mathrm{be} \mathrm{in} \mathrm{a} \mathrm{porous}$ and permeable weathered layer of medium-high groundwater potential. It is within the optimum weathering resistivity variation of 20 to $100 \Omega \mathrm{m}$ and moderate aquifer protective capacity. Four VES positions in Table 6 are therefore recommended based on the aforementioned factors. 


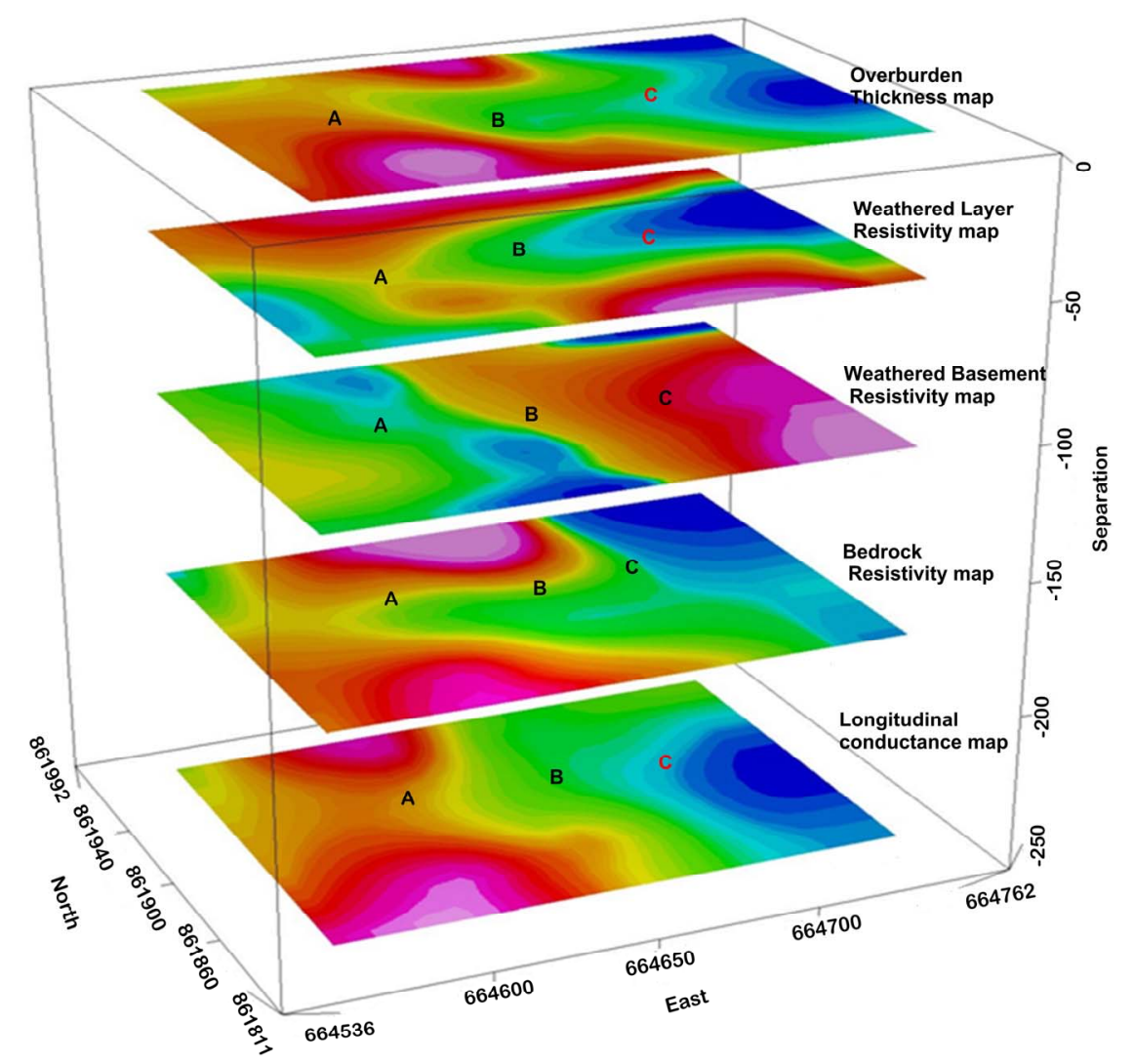

Figure 12. 3D map display and selected positions (highest values in red/purple down to the lowest values in deep blue).

Table 5. Characteristics of important areas identified in the various maps (Figure 12).

\begin{tabular}{|c|c|c|c|}
\hline Parameters & $\mathrm{A} \approx 25 \mathrm{~m}$ from dumpsite & $\mathrm{B} \approx 50 \mathrm{~m}$ from dumpsite & $\mathrm{C} \approx 95 \mathrm{~m}$ from dumpsite \\
\hline Overburden & $\begin{array}{l}\text { Relatively high }>2-<40 \mathrm{~m} \text {. } \\
\text { Medium/high groundwater potential }\end{array}$ & $\begin{array}{l}\text { Relatively moderate }>10-<20 \mathrm{~m} \\
\text { Low groundwater potential }\end{array}$ & $\begin{array}{l}\text { Relatively high }(<10 \mathrm{~m}) \\
\text { Minimal groundwater } \\
\text { potential }\end{array}$ \\
\hline $\begin{array}{l}\text { Weathered layer } \\
\text { resistivity }\end{array}$ & $\begin{array}{l}\text { Resistivity }(100-250 \Omega \mathrm{m}) \\
\text { Medium groundwater potential }\end{array}$ & $\begin{array}{l}\text { Resistivity }(100-250 \Omega \mathrm{m}) \\
\text { Medium groundwater potential }\end{array}$ & $\begin{array}{l}\text { Resistivity }(<100 \Omega \mathrm{m}) \\
\text { Low groundwater potential }\end{array}$ \\
\hline $\begin{array}{l}\text { Weathered } \\
\text { basement } \\
\text { resistivity }\end{array}$ & $\begin{array}{l}\text { Resistivity }(20-100 \Omega \mathrm{m}) \\
\text { Optimum weathering and } \\
\text { groundwater potential }\end{array}$ & $\begin{array}{l}\text { Resistivity (101 - } 150 \Omega \mathrm{m}) \text { Medium } \\
\text { aquifer condition and potential }\end{array}$ & $\begin{array}{l}\text { Resistivity }(>151 \Omega \mathrm{m}) \\
\text { Limited/Negligible } \\
\text { weathering and poor potential. }\end{array}$ \\
\hline $\begin{array}{l}\text { Bedrock } \\
\text { resistivity }\end{array}$ & $\begin{array}{l}\text { Resistivity ( }>3000 \Omega \mathrm{m}) \\
\text { Negligible aquifer potential }\end{array}$ & $\begin{array}{l}\text { Resistivity }(1501-3000 \Omega \mathrm{m}) \text { Low aquifer } \\
\text { potential }\end{array}$ & $\begin{array}{l}\text { Resistivity }(<750 \Omega \mathrm{m}) \\
\text { High aquifer potential }\end{array}$ \\
\hline $\begin{array}{l}\text { Longitudinal } \\
\text { conductance }\end{array}$ & $\begin{array}{l}0.2-0.69 \\
\text { Moderately protected }\end{array}$ & $0.1-0.69$ Moderately/weakly protected & $<0.1$ Poorly protected \\
\hline
\end{tabular}

Table 6. Recommended VES points for groundwater abstraction.

\begin{tabular}{|c|c|c|c|c|c|c|c|}
\hline $\begin{array}{l}\text { VES } \\
\text { NO }\end{array}$ & $\begin{array}{l}\text { Clay cover resistivity } \\
(\Omega \mathrm{m})\end{array}$ & $\begin{array}{l}\text { Clay } \\
\text { thickness } \\
\text { (m) }\end{array}$ & $\begin{array}{l}\text { Over burden thickness } \\
\qquad(\mathrm{m})\end{array}$ & $\begin{array}{l}\text { Weathered } \\
\text { layer } \\
\text { resistivity } \\
(\Omega \mathrm{m})\end{array}$ & $\begin{array}{l}\text { Weathered } \\
\text { basement } \\
\text { resistivity } \\
(\Omega \mathrm{m})\end{array}$ & $\begin{array}{l}\text { Longitudinal } \\
\text { conductance }\end{array}$ & $\begin{array}{c}\text { Protective } \\
\text { capacity } \\
\text { rating }\end{array}$ \\
\hline 3 & 73 & 3.7 & 22.1 & 271 & 31 & 0.509 & Moderate \\
\hline 6 & 78 & 2.8 & 33.7 & 212 & 54 & 0.555 & Moderate \\
\hline 8 & 91 & 3.5 & 22.5 & 210 & 47 & 0.370 & Moderate \\
\hline 13 & 52 & 3.1 & 25.0 & 161 & 54 & 0.398 & Moderate \\
\hline
\end{tabular}




\section{Acknowledgements}

The first author sincerely appreciates Federal Ministry of Education, Nigeria for the scholarship grant and Osun State Environmental Protection Agency for granting permission to use the dumpsite. Mr. Mamukuyomi Abiodun assisted during data acquisition. He is gratefully acknowledged.

\section{References}

[1] Margat, J. and van der Gun, J. (2013) Groundwater around the World: A Geographic Synopsis. CRC Press/Balkema. Leiden.

[2] Rahaman, M.A. (1988) Recent Advances in the Study of the Basement Complex of Nigeria. In Precambrian Geology of Nigeria, Geological Survey of Nigeria, Kaduna South, 11-43.

[3] Al-Garni, M.A. (2009) Geophysical Investigations for Groundwater in a Complex Subsurface. Terrain, Wadi Fatima, KSA: A Case History. Jordan Journal of Civil Engineering, 3, 118-136.

[4] Barker, R.D. (2001) Imaging Fractures in Hard Rock Terrain. University of Birmingham, UK. http://www.bham.ac.uk/EarthSciences/research/hydro/envgeo/

[5] Efe, S.I. (2002) Urban Warming in Nigerian Cities. The Case of Warri Metropolis. African Journal of Environmental Studies, 3, 160-168.

[6] Koefoed, O.C. (1979) Geosounding Principles 1: Resistivity Sounding Measurements. Elsevier Science Publishing Company, Amsterdam.

[7] McDowell, P.W. (1979) Geophysical Mapping of Water Filled Fracture Zones in Rocks. International Association of Engineering Geology Bulletin, 19, 258-264. http://dx.doi.org/10.1007/BF02600485

[8] Ayolabi, E.A., Adedeji, J.K. and Oladapo, I.M. (2003) A Geoelectric Mapping of Ijapo, Akure South Western Nigeria and Its Hydrogeological Implications. Global Journal of Pure and Applied Sciences, 10, 441-446.

[9] Ayolabi, E.A., Folorunso, A.F., Eleyinmi, A.F., Esther, O. and Anuyah, E.O. (2009) Applications of 1D and 2D Electrical Resistivity Methods to Map Aquifers in a Complex Geologic Terrain of Foursquare Camp, Ajebo, Southwestern Nigeria. The Pacific Journal of Science and Technology, 10, 657-666.

[10] Sharma, S.P. and Baranwal, V.C. (2005) Delineation of Groundwater-Bearing Fracture Zone in a Hardrock Area Integrating Very Low Frequency Electromagnetic and Resistivity Data. Journal of Applied Geophysics, 57, 155-166. http://dx.doi.org/10.1016/j.jappgeo.2004.10.003

[11] Griffiths D.H. and Barker, R.D. (1993) Two-Dimensional Resistivity Imaging and Modeling in Areas of Complex Geology. Journal of Applied Geophysics, 29, 21-26. http://dx.doi.org/10.1016/0926-9851(93)90005-J

[12] Loke, M.H. (2000) A Practical Guide to 2-D and 3-D Surveys. http://www.heritagegeophysics.com

[13] Zhou, Q.Y., Matsui, H. and Shimada, J. (2004) Characterization of the Unsaturated Zone around a Cavity in Fractured Rocks Using Electrical Resistivity Tomography. Journal of Hydraulic Research, 42, 25-31. http://dx.doi.org/10.1080/00221680409500044

[14] Roa, B.V., Prasad, Y.S. and Reddy, K.S. (2013) Hydrogeophysical Investigations in a Typical Khondalitic Terrain to Delineate the Kaolinised Layer Using Resistivity Imaging. Journal Geological Society of India, 81, 521-530. http://dx.doi.org/10.1007/s12594-013-0067-x

[15] Rahaman, M.A. (1989) Review of the Basement Geology of Southwestern Nigeria. In: Kogbe, C.A., Ed., Geology of Nigeria, Elizabeth Publishing Co., Nigeria, 41-58.

[16] Oyelami, A.C., Ojo, A.O., Aladejana, J.A. and Agbede, O.O. (2013) Assessing the Effect of a Dumpsite on Groundwater Quality: A Case Study of Aduramigba Estate within Osogbo Metropolis. Journal of Environment and Earth Science, 3, 2224-3216.

[17] Vander-Velpen, B.P.A. (2004) WinRESIST Version 1.0 Resistivity Depth Sounding Interpretation Software. M.Sc Research Project, ITC, Delft, the Netherland.

[18] Henriet, J.P. (1976) Direct Application of the Dar Zarrouk Parameters in Groundwater Surveys. Geophysical Prospecting, 2, 344-353. http://dx.doi.org/10.1111/j.1365-2478.1976.tb00931.x

[19] Smith, W.H.F. and Wessel, P. (1990) Gridding with Continuous Curvature Splines in Tension. Geophysics, 55, 293305. http://dx.doi.org/10.1190/1.1442837

[20] Olayinka, A.I., Amidu, S.A. and Oladunjoye, M.A. (2004) Use of Electromagnetic Profiling and Resistivity Sounding for Groundwater Exploration in the Crystalline Basement Area of Igbeti, Southwestern Nigeria. Global Journal of Geological Sciences, 2, 243-253. http://dx.doi.org/10.4314/gjgs.v2i2.18701

[21] Akintorinwa, O.J. (2015) Groundwater Potential Assessment of Iwaro-Oka, SW Nigeria Using Geoelectric Parameters. 
British Journal of Applied Science \& Technology, 6, 364-377. http://dx.doi.org/10.9734/BJAST/2015/14584

[22] Omosuyi, G.O. (2010) Geoelectric Assessment of Groundwater Prospect and Vulnerability of Overburden Aquifers at Idanre, Southwestern Nigeria. Ozean Journal of Applied Science, 3, 19-28.

[23] Worthington, P.R. (1977) Geophysical Investigations of Groundwater Resources in the Kalahari Basin. Geophysics, 42, 838-849. http://dx.doi.org/10.1190/1.1440751

[24] Olayinka, A.I. and Olorunfemi, M.O. (1992) Determination of Geoelectric Characteristics in Okene Area and Implications for Borehole Siting. Journal of Mining and Geology, 28, 403-411.

[25] Adelusi, A.O., Ayuk, M.A. and Oyedele, A.A. (2004) Hydrogeophysical Analysis of Owode Area around Oba-Ile near Akure, SW Nigeria. African Journal of Development Studies, 4, 11-14.

[26] Mallam, A. (2004) Fresh Basement: Revealed from Resistivity Method. Zuma Journal of Pure and Applied Sciences, 6 , 6-9.

[27] Wright, E.P. (1992) The Hydrogeology of Crystalline Basement Aquifers in Africa. Geological Society of London, Special Publications, 66, 1-27. http://dx.doi.org/10.1144/GSL.SP.1992.066.01.01

[28] Oyedele, E.A.A. and Olayinka, A.I. (2012) Statistical Evaluation of Groundwater Potential of Ado-Ekiti, Southwest Nigeria. Transnational Journal of Science and Technology, 2, 110-127.

[29] Shemang Jr., E.N. (1993) Groundwater Potentials of Kubanni River Basin, Zaria, Nigeria from DC Resistivity Study. Water Resources, 4, 36-42.

[30] Aboh, H.O. and Osazuwa, I.B. (2000) Lithological Deductions from Regional Geoelectric Investigation in Kaduna, Kaduna State Nigeria. Nigerian Journal of Physics, 12, 1-7.

[31] Olorunfemi, M.O. and Fasuyi, S.A. (1993) Aquifer Types and the Geoelectric/Hydrogeologic Characteristics of Part of Central Basement Terrain of Nigeria (Niger State). Journal of African Earth Sciences, 16, 309-317. http://dx.doi.org/10.1016/0899-5362(93)90051-Q

[32] Bala, A.E. and Ike, E.C. (2001) The Aquifer of the Crystalline Basement Rocks in Gusau Area, North-Western Nigeria. Journal of Mining and Geology, 37, 177-184.

[33] Omosuyi, G.O., Ojo, J.S. and Enikanselu, P.A. (2003) Geophysical Investigation for Groundwater around Obanla-Obakekere in Akure Area within the Basement Complex of South-Western Nigeria. Journal of Mining and Geology, 39, 109-116.

[34] Olayinka, A.I., Akpan, E.J. and Magbagbeola, O.A. (1997) Geoelectric Sounding for Estimating Aquifer Potential in the Crystalline Basement Area around Shaki, Southwest Nigeria. Water Resources, 8, 71-81.

[35] Olorunfemi, M.O., Ojo, J.S. and Akintunde, M.O. (1999) Hydrogeophysical Evaluation of the Groundwater Potentials of the Akure Metropolis. Journal of Mining and Geology, 35, 207-228.

[36] Oladapo, M.I., Mohammed, M.Z., Adeoye, O.O. and Adetola, B.A. (2004) Geoelectrical Investigation of the Ondo State Housing Corporation Estate, Ijapo Akure, Southwestern Nigeria. Journal of Mining and Geology, 40, 41-48. http://dx.doi.org/10.4314/jmg.v40i1.18807

[37] Oladapo, M.I. and Akintorinwa, O.J. (2007) Hydrogeophysical Study of Ogbese, Southwestern, Nigeria. Global Journal of Pure and Applied Sciences, 13, 55-61. http://dx.doi.org/10.4314/gipas.v13i1.16669

[38] Abiola, O., Enikanselu, P.A. and Oladapo, M.I. (2009) Groundwater Potential and Aquifer Protective Capacity of Overburden Units in Ado-Ekiti, Southwestern Nigeria. International Journal of Physical Sciences, 4, 120-132.

[39] Akintorinwa, O.J. and Abiola, O. (2012) Comparison of Schlumberger and Modified Schlumberger Arrays VES Interpretation Results. Research Journal in Engineering and Applied Sciences, 1, 190-196.

[40] Olorunfemi, M.O. and Okhue, E.J. (1992) Hyrogeologic and Geologic Significance of a Geoelectric Survey at Ile-Ife, Nigeria. Journal of Mining and Geology, 28, 242-350.

[41] White, C.C., Huston, J.T.F. and Baker, R.D. (1988) The Victoria Province Drought Relief Project 1. Geophysical Sitting of Boreholes. Groundwater, 26, 309-316. http://dx.doi.org/10.1111/j.1745-6584.1988.tb00394.x

[42] Lenkey, L., Hamori, Z. and Mihalffy, P. (2005) Investigating the Hydrogeology of a Water-Supply Area Using Direct-Current Vertical Electrical Sounding. Geophysics, 70, 1-19. http://dx.doi.org/10.1190/1.2000288

[43] Ojo, A.O., Oyelami, C.A. and Adereti, A.O. (2014) Hydro-Geochemical and Geophysical Study of Groundwater in the Suburb of Osogbo, South Western Nigeria. Journal of Earth Science \& Climatic Change, 5, 205.

[44] Ariyo, S.O., Omosanya, K.O. and Oshinloye, B.A. (2013) Electrical Resistivity Imaging of Contaminant Zone at Sotubo Dumpsite along Sagamu-Ikorodu Road, Southwestern Nigeria. African Journal of Environmental Science and Technology, 7, 312-320. 